Geology and Assessment of Undiscovered Oil and Gas Resources of the Northern West Siberian Mesozoic Composite Total Petroleum System of the West Siberian Basin Province, Russia, 2008

Chapter 0 of

The 2008 Circum-Arctic Resource Appraisal

Professional Paper 1824 
Eocene strata along the north side of Van Keulenfjorden, Svalbard, include basin-floor fan, marine slope, and deltaic to fluvial depositional facies. The age and facies of these strata are similar to Tertiary strata beneath the continental shelves of Arctic Eurasia, thus providing an analog for evaluating elements of those petroleum systems. Relief from sea level to top of upper bluff is approximately 1,500 feet. Photograph by David Houseknecht. 


\section{Geology and Assessment of Undiscovered Oil and Gas Resources of the Northern West Siberian Mesozoic Composite Total Petroleum System of the West Siberian Basin Province, Russia, 2008}

By Christopher J. Schenk

Chapter 0 of

The 2008 Circum-Arctic Resource Appraisal

Edited by T.E. Moore and D.L. Gautier

Professional Paper 1824 


\section{U.S. Department of the Interior RYAN K. ZINKE, Secretary}

\section{U.S. Geological Survey James F. Reilly II, Director}

\section{U.S. Geological Survey, Reston, Virginia: 2018}

For more information on the USGS - the Federal source for science about the Earth, its natural and living resources, natural hazards, and the environment-visit https://www.usgs.gov or call 1-888-ASK-USGS.

For an overview of USGS information products, including maps, imagery, and publications, visit https://store.usgs.gov.

Any use of trade, firm, or product names is for descriptive purposes only and does not imply endorsement by the U.S. Government.

Although this information product, for the most part, is in the public domain, it also may contain copyrighted materials as noted in the text. Permission to reproduce copyrighted items must be secured from the copyright owner.

Suggested citation:

Schenk, C.J., 2018, Geology and assessment of undiscovered oil and gas resources of the Northern West Siberian Mesozoic Composite Total Petroleum System of the West Siberian Basin Province, Russia, 2008, chap. 0 of Moore, T.E., and Gautier, D.L., eds., The 2008 Circum-Arctic Resource Appraisal: U.S. Geological Survey Professional Paper 1824, 26 p., https://doi.org/10.3133/pp18240.

ISSN 2330-7102 (online) 


\section{The 2008 Circum-Arctic Resource Appraisal}

\section{Chapters}

A. Introduction to the 2008 Circum-Arctic Resource Appraisal (CARA) Professional Paper By Donald L. Gautier and Thomas E. Moore

B. Methodology for Assessment of Undiscovered Oil and Gas Resources for the 2008 Circum-Arctic Resource Appraisal

By Ronald R. Charpentier

\section{North America}

C. Geology and Assessment of Undiscovered Oil and Gas Resources of the Chukchi Borderland Province, 2008

By Kenneth J. Bird and David W. Houseknecht

D. Geology and Assessment of Undiscovered Oil and Gas Resources of the Hope Basin

Province, 2008

By Kenneth J. Bird, David W. Houseknecht, and Janet K. Pitman

E. Geology and Assessment of Undiscovered Oil and Gas Resources of the Arctic Alaska Petroleum Province, 2008

By David W. Houseknecht, Kenneth J. Bird, and Christopher P. Garrity

F. Geology and Assessment of Undiscovered Oil and Gas Resources of the Yukon Flats Basin Province, 2008

By Kenneth J. Bird and Richard G. Stanley

G. Geology and Assessment of Undiscovered Oil and Gas Resources of the Northwest Canada Interior Basins Province, Arctic Canada, 2008

By Marilyn E. Tennyson and Janet K. Pitman

H. Geology and Assessment of Undiscovered Oil and Gas Resources of the Franklinian Shelf Province, Arctic Canada and North Greenland, 2008

By Marilyn E. Tennyson and Janet K. Pitman

I. Geology and Assessment of Undiscovered Oil and Gas Resources of the Sverdrup Basin Province, Arctic Canada, 2008

By Marilyn E. Tennyson and Janet K. Pitman

\section{Greenland}

J. Geology and Assessment of Undiscovered Oil and Gas Resources of the West GreenlandEast Canada Province, 2008

By Christopher J. Schenk 
K. Geology and Assessment of Undiscovered Oil and Gas Resources of the East Greenland Rift Basins Province, 2008

By Donald L. Gautier

\section{North Atlantic Ocean}

L. Geology and Assessment of Undiscovered Oil and Gas Resources of the Jan Mayen Microcontinent Province, 2008

By Thomas E. Moore and Janet K. Pitman

\section{Eurasia}

M. Geology and Assessment of Undiscovered Oil and Gas Resources of the Mezen' Basin Province, 2008

By Timothy R. Klett and Janet K. Pitman

N. Geology and Assessment of Undiscovered Oil and Gas Resources of the Timan-Pechora Basin Province, Russia, 2008

By Christopher J. Schenk

0. Geology and Assessment of Undiscovered Oil and Gas Resources of the East Barents Basins Province and the Novaya Zemlya Basins and Admiralty Arch Province

By Timothy R. Klett

P. Geology and Assessment of Undiscovered Oil and Gas Resources of the North Kara Basins and Platforms Province, 2008

By Timothy R. Klett and Janet K. Pitman

0. Geology and Assessment of Undiscovered Oil and Gas Resources of the Northern West Siberian Mesozoic Composite Total Petroleum System of the West Siberian Basin Province, Russia, 2008

By Christopher J. Schenk

R. Geology and Assessment of Undiscovered Oil and Gas Resources of the Yenisey-Khatanga Basin Province, 2008

By Timothy R. Klett and Janet K. Pitman

S. Geology and Assessment of Undiscovered Oil and Gas Resources of the Northwest Laptev Sea Shelf Province, 2008

By Timothy R. Klett and Janet K. Pitman

T. Geology and Assessment of Undiscovered Oil and Gas Resources of the Lena-Anabar Basin Province, 2008

By Timothy R. Klett and Janet K. Pitman 
U. Geology and Assessment of Undiscovered Oil and Gas Resources of the Tunguska Basin Province, 2008

By Craig J. Wandrey and Timothy R. Klett

V. Geology and Assessment of Undiscovered Oil and Gas Resources of the Lena-Vilyui Basin Province, 2008

By Timothy R. Klett and Janet K. Pitman

W. Geology and Assessment of Undiscovered Oil and Gas Resources of the Laptev Sea Shelf Province, 2008

By Timothy R. Klett and Janet K. Pitman

X. Geology and Assessment of Undiscovered Oil and Gas Resources of the Zyryanka Basin Province, 2008

By Timothy R. Klett and Janet K. Pitman

Y. Geology and Assessment of Undiscovered Oil and Gas Resources of the East Siberian Sea Basin Province, 2008

By Kenneth J. Bird, David W. Houseknecht, and Janet K. Pitman

Z. Geology and Assessment of Undiscovered Oil and Gas Resources of the Vilkitskii Basin Province, 2008

By Kenneth J. Bird, David W. Houseknecht, and Janet K. Pitman

AA. Geology and Assessment of Undiscovered Oil and Gas Resources of the Long Strait Province, Russian High Arctic, 2008

By Kenneth J. Bird, David W. Houseknecht, and Janet K. Pitman

\section{Arctic Ocean}

BB. Geology and Assessment of Undiscovered Oil and Gas Resources of the Amerasia Basin Petroleum Province, 2008

By David W. Houseknecht, Kenneth J. Bird, and Christopher P. Garrity

CC. Geology and Assessment of Undiscovered Oil and Gas Resources of the LomonosovMakarov Province, Central Arctic Ocean, 2008

By Thomas E. Moore, Kenneth J. Bird, and Janet K. Pitman

DD. Geology and Assessment of Undiscovered Oil and Gas Resources of the Eurasia Basin Province, Eastern Arctic Ocean, 2008

By Thomas E. Moore and Janet K. Pitman 


\section{Contents}

Abstract
Introduction
West Siberian Basin Province Boundary Definition
Tectonic Evolution of the West Siberian Basin
Stratigraphy of the West Siberian Basin Province
Northern West Siberian Mesozoic Composite Total Petroleum System Description
Tssessment Unit Descriptions
$\quad$ Georthern West Siberian Onshore Gas AU Description
Geologic Anal Analysis of AU Probability

\section{Appendixes}

[Available for download at https://doi.org/10.3133/pp1824Q]

1. Input Data for the Northern West Siberian Onshore Gas Assessment Unit

2. Input data for the South Kara Sea Offshore Assessment Unit

3. Detailed Assessment Results for the Northern West Siberian Onshore Gas Assessment Unit

4. Detailed Assessment Results for the South Kara Sea Offshore Assessment Unit 


\section{Figures}

1. Location map of West Siberian Basin Province, Russia..................................................................

2. Geologic map of the greater West Siberian Basin, Russia ...........................................................

3. Schematic plate kinematic model describing the complex convergent tectonics of the margins of the East European, Siberian, and Kazakh-Altay plates that converged by the Permian to form Pangea...

4. Diagram showing tectonic evolution of the southern part of the Uralian orogenic belt along the western margin of the West Siberian Basin Province, Russia

5. Schematic illustration of the complex heterogeneous basement of the West Siberian Basin

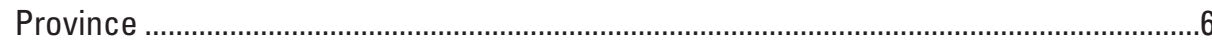

6. Stratigraphic column for the West Siberian Basin Province modified from Ulmishek...............8

7. Regional cross sections of the West Siberian Basin Province. Modified from Petersen and Clarke.

8. Map showing the boundary of the Northern West Siberian Mesozoic Composite Total Petroleum System for the northern part of the West Siberian Basin Province.

9. Isopach map showing thickness and extent of the Tithonian to Berriasian section in the West Siberian Basin Province, which is largely organic-rich source rock facies of the Bazhenov Formation.

10. Maps of Total Organic Carbon and thermal maturity of the Upper Jurassic Bazhenov Formation source rock facies in the West Siberian Basin Province

11. Geologic model for the definition and development of the Northern West Siberian Mesozoic Composite Total Petroleum System.

12. Total petroleum system events chart for the Northern West Siberian Onshore Gas Assessment Unit

13. Plot of grown sizes and numbers of oil and gas fields in the Northern West Siberian Onshore Gas Assessment Unit 11740301

14. Map of identified prospects and discovered gas fields in part of the South Kara Sea Offshore Assessment Unit.

15. Structural cross sections in the South Kara Sea area illustrating the effect of basement structure on the overlying Mesozoic sedimentary section..

16. Total petroleum system events chart for the South Kara Sea Offshore Assessment Unit ....21

\section{Tables}

1. Northern West Siberian Mesozoic Composite Total Petroleum System assessment results 



\title{
Chapter 0
}

\section{Geology and Assessment of Undiscovered Oil and Gas Resources of the Northern West Siberian Mesozoic Composite Total Petroleum System of the West Siberian Basin Province, Russia, 2008}

\author{
By Christopher J. Schenk
}

\begin{abstract}
The West Siberian Basin Province is one of the largest sedimentary basins in the world, with an area of 2.6 million square kilometers, and the basin ranks first in the world with more than 400 billion barrels of oil-equivalent discovered petroleum. For the 2008 Circum-Arctic Resource Appraisal, the U.S. Geological Survey defined a Northern West Siberian Mesozoic Composite Total Petroleum System (TPS) and two geologic assessment unit (AUs) within this composite TPS that are north or partially north of the Arctic Circle. The Northern West Siberian Onshore Gas AU was defined to encompass all potential structures, traps, and reservoirs in the onshore part of the Composite TPS. The South Kara Sea Offshore AU was defined to include all potential structures, traps, and reservoirs within the thick sedimentary section that extends offshore from the Northern West Siberian Onshore Gas AU.

For the Northern West Siberian Mesozoic Composite TPS, the total mean estimates for undiscovered conventional oil and gas resources (table 1) are 4.1 billion barrels of oil (BBO), 663 trillion cubic feet of gas (TCFG), and 20.7 billion barrels of natural gas liquids (BBNGL). For areas of the AUs north of the Arctic Circle in the West Siberian Basin Province, the total mean estimates for undiscovered conventional resources are 3.7 BBO, $651 \mathrm{TCFG}$, and 20.3 BBNGL. The total mean estimates for undiscovered oil and gas north of the Arctic Circle for the Northern West Siberian Onshore Gas AU are 1.2 BBO, 29.3 TCFG, and 0.85 BBNGL. Mean estimates for the South Kara Sea Offshore AU are 2.5 BBO, 622.2 TCFG, and 19.5 BBNGL. The estimate for undiscovered conventional gas resources for the South Kara Sea Offshore AU is the most of any AU in the Circum-Arctic study.
\end{abstract}

\section{Introduction}

The purpose of this paper is to document the geologic input to a quantitative assessment of undiscovered conventional oil and gas resources in the part of the West Siberian Basin Province of Russia that extends above the Arctic Circle (fig. 1), as part of the 2008 U.S. Geological Survey (USGS) Circum-Arctic petroleum assessment (Gautier and others, 2009). This study evaluated the potential for undiscovered conventional oil and gas resources; unconventional resources such as shale oil, shale gas, or tight gas were not included in this assessment.

The West Siberian Basin Province has a long history of oil and gas exploration and production summarized by Ulmishek (2003). The first gas field was discovered in 195 on the western margin of the basin and several hundred oil and gas fields have been discovered since that time. Most of the giant and supergiant conventional oil and gas fields were discovered in the 1960s and 1970s. The sizes of discovered fields have declined with time, but opportunities remain for future exploration, particularly in the northern part of the basin which is the subject of this report. Nearly all of the large structural traps have been drilled and tested onshore, but offshore structural objectives and stratigraphic traps across the basin such as incised valley fill reservoirs will likely be the focus of future exploration. In the northern part of the basin, with more than 15 kilometers $(\mathrm{km})$ of sedimentary rock, deeper undrilled objectives are possible, particularly for gas.

The USGS assessment process for the West Siberian Basin Province began with a formal review of the geology of the province, including the tectonic and stratigraphic evolution, analysis of petroleum systems and petroleum system elements (traps, seals, reservoirs, source rocks, and timing of events), analysis of exploration results (discovered fields and dry holes), discovery history, and potential geologic and production analogs. The next step was to develop a geologic model based on the geologic review that could be used as a framework for the assessment of undiscovered conventional oil and gas resources. After summarizing all geology and production information, undiscovered resources were quantified by developing probability distributions for sizes and numbers of undiscovered fields, incorporating the geologic uncertainty summarized in the geologic analysis. 


\section{West Siberian Basin Province Boundary Definition}

The West Siberian Basin Province, as defined for this study, is an area of about 2.6 million square kilometers $\left(\mathrm{km}^{2}\right)$. The province is located between the East European craton/ Uralian orogenic belt to the west, the Siberian craton to the east, the Kazakh and Altay-Sayan uplifts to the south, and the Novaya Zemlya fold and thrust belt and Siberian sill to the north and northeast (fig. 1; Nesterov and others, 1990). The West Siberian Basin Province represents one of the largest sedimentary basins in the world. The general geologic map of the West Siberian Basin Province and the surrounding areas is shown in figure 2. For this study the main e fort was to assess undiscovered conventional oil and gas resources in the part of the West Siberian Basin Province north of the Arctic Circle.

\section{Tectonic Evolution of the West Siberian Basin}

The West Siberian Basin is a Mesozoic-Cenozoic sedimentary basin developed on heterogeneous Proterozoic, Paleozoic, and Triassic basement. Basement rocks of the West Siberian Basin reflect a series of complex tectonic events a fecting the margins of the East European plate, Siberian plate, and Kazakh-Altay-Sayan plate from Devonian to early Permian time, when final accretion resulted in the suturing of the area that now forms the basement of the West Siberian Basin (figs. 3, 4). According to Aplonov (1995), the basement of the West Siberian Basin is a sutured mosaic of convergent tectonic units (such as extinct island arcs, marginal seas, continental island arcs), micro-continents, ophiolites, possible relict ocean basins, and rift-related rock assemblages (fig. 5), that when

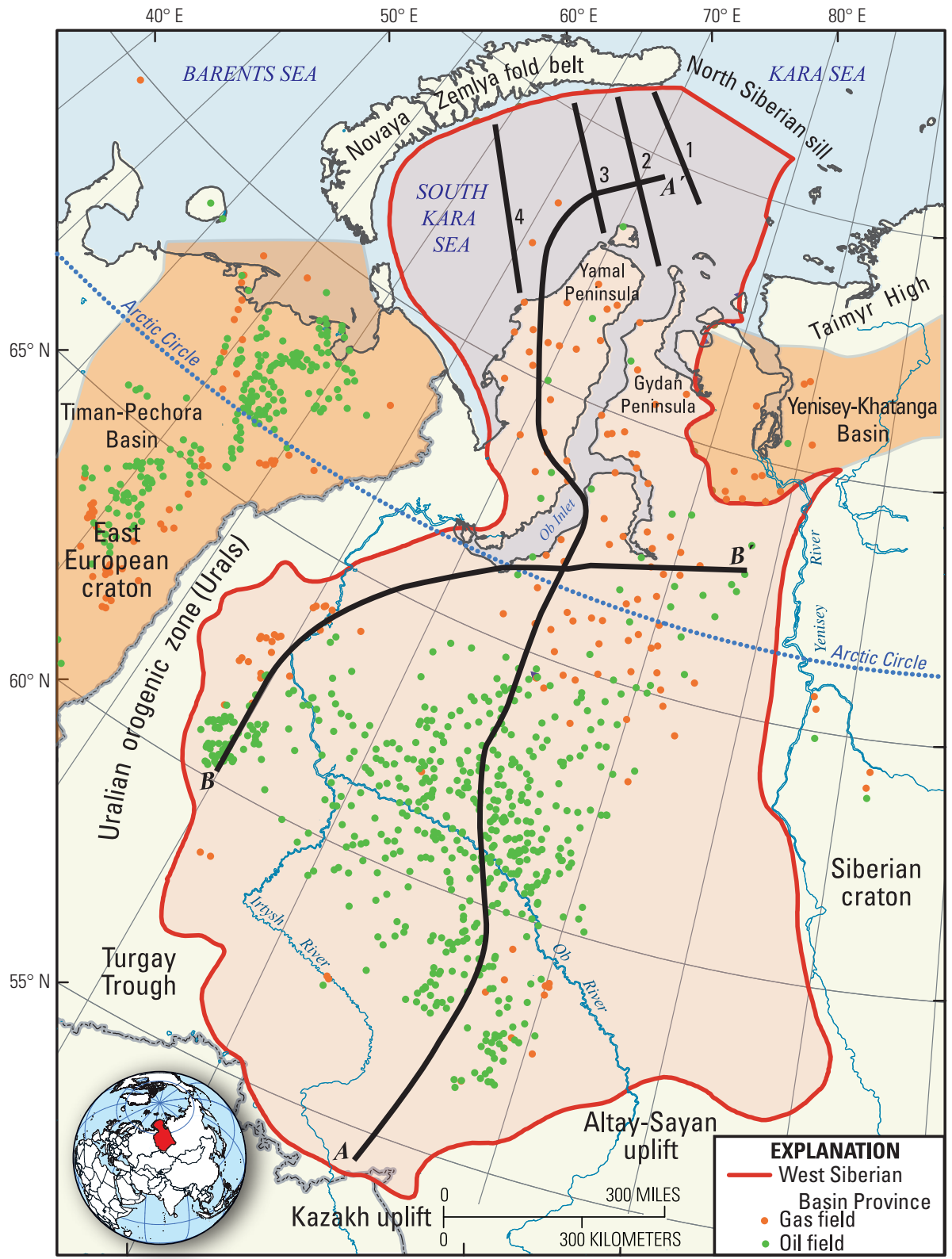

Figure 1. Location map of West Siberian Basin Province, Russia. Boundary of the USGS-defined province is shown by red line. Cross sections of lines $A-A^{\prime}$ and $B-B^{\prime}$ are shown in figure $7 A$ and $B$; cross sections of lines 1-4 in the South Kara Sea are shown in figure 15. 


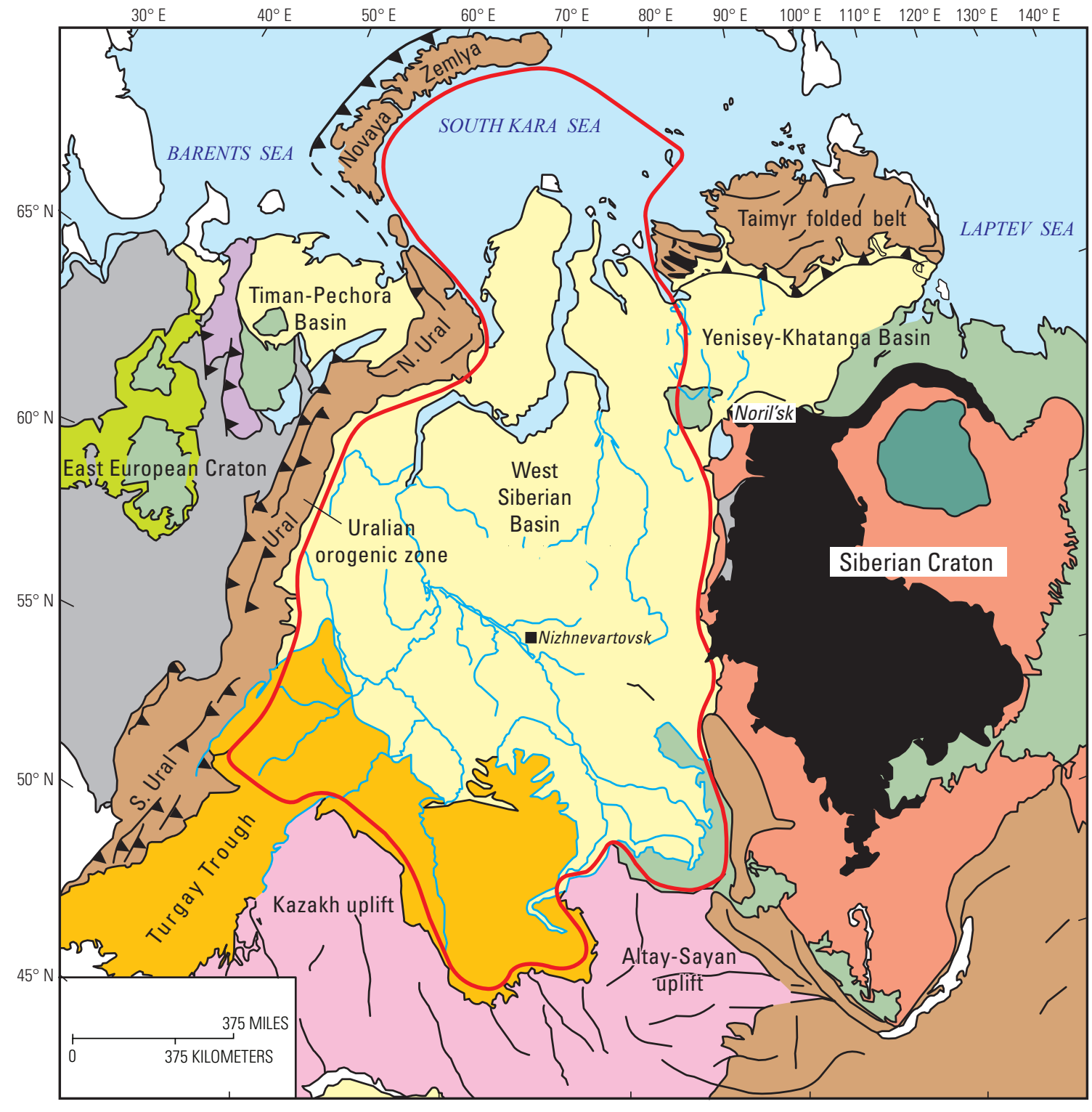

EXPLANATION

\begin{tabular}{|c|}
\hline Quaternary (Siliciclastics) \\
\hline Tertiary (Siliciclastics) \\
\hline Jurassic-Cretaceous \\
\hline Siberian basalts \\
\hline Triassic \\
\hline Carboniferous-Permian \\
\hline Devonian-Permian \\
\hline Ordovician-Carboniferous \\
\hline
\end{tabular}

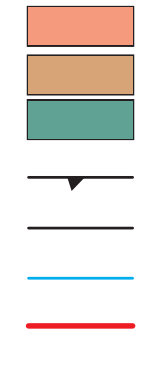

Cambrian-Ordovician (Platform)

Precambrian-Paleozoic Archean

Thrust fault Fault River

Basin boundary
Figure 2. Geologic map of the greater West Siberian Basin, Russia. Modified from Vyssotski and others (2006). The West Siberian Basin is situated between the Siberian craton, the Kazakh and Altay-Sayan uplifts, and the Uralian orogenic zone adjacent to the East European craton. The YeniseyKhatanga Basin and Turgay Trough areas are not included in the West Siberian Basin Province. accreted to the surrounding cratonic areas ultimately led to the assembly of Pangea (Hamilton, 1970; Scarrow and others, 2002; Surkov and others, 2004; Vyssotski and others, 2006; Görz and Hielscher, 2010). The basement of the West Siberian Basin, along with parts of the Kazakh and Altay-Sayan uplifts, form what are called the West Siberian Altaids (Görz and
Hielscher, 2010). By Permian time the basement of the West Siberian Basin was a coherent entity, but the heterogeneous nature of the basement formed a zone of crustal weakness compared to adjacent cratonic areas (Aplonov, 1995; Scarrow and others, 2002), and this weakness figured prominently in the subsequent location of the West Siberian Basin. 


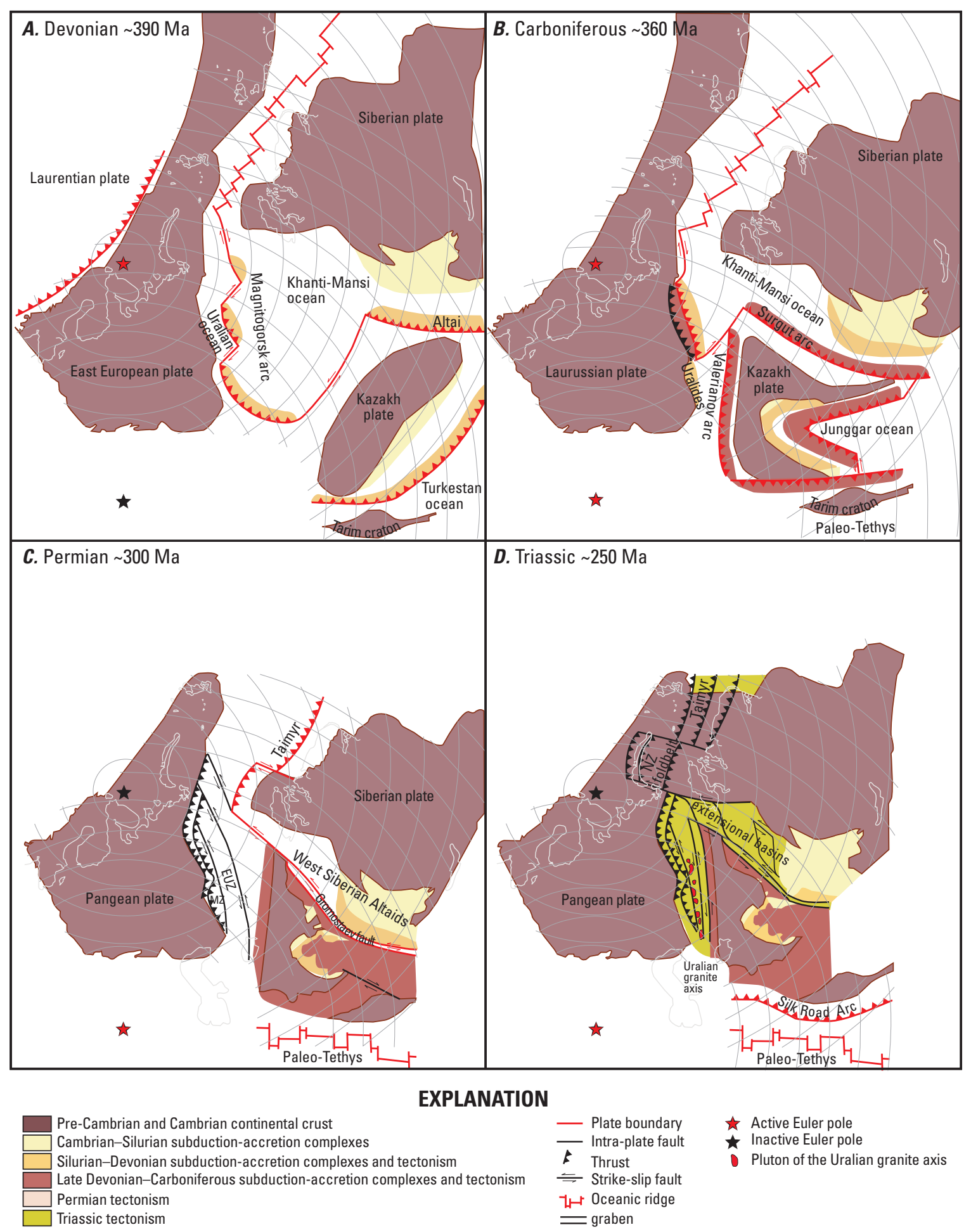

Figure 3. Schematic plate kinematic model describing the complex convergent tectonics of the margins of the East European, Siberian, and Kazakh-Altay plates that converged by the Permian to form Pangea. The Uralian and Altaid orogenic areas between the three cratonic areas form the complex basement of the West Siberian Basin that eventually was the focus of Triassic rifting and formation of extensional basins. $A$, In the Devonian several magmatic arcs were active, including the Magnitogorsk and Altai arcs. $B$, In the Carboniferous, continued convergence led to accretion of arcs, closure of the Uralian ocean, and continued closure of the Khanti-Mansi ocean. Arcs nearly surrounded the Kazakh plate. C, By the Permian final suturing resulted in the formation of the single continent of Pangea, with cratonic areas separated by the Uralian and Altaid orogenic assemblages. $D$, Extensional basins formed in the basement of the West Siberian Basin in the Triassic. MZ, Magnitogorsk Zone; EUZ, East Uralian Zone; NZ, Novaya Zemlya; Ma, million years ago. Modified from Görz and Hielscher (2010). 
The Uralian orogenic zone along the western margin of the West Siberian Basin is perhaps one of the best studied orogenic belts in the world (fig. 1), and the Urals record the accretion of subduction-related rock assemblages to the East European craton from the Devonian to late Carboniferous. Exposures in the Urals represent rock assemblages that are similar to those within the basement of the West Siberian Basin, and the Uralian orogenic belt extends beneath the basin
(Ulmishek, 2003). The complex convergent tectonic history of the Uralian orogenic zone is well known and many studies have documented the rock assemblages formed during closure of the various paleo-oceans (Savelieva and Nesbitt, 1996; Brown and others, 1997; Juhlin and others, 1998; Ayarza and others, 2000; Scarrow and others, 2002; Puchkov, 2009; Brown, 2009; Görz and Hielscher, 2010). The Novaya Zemlya fold belt (fig. 1), the northern extension of the Urals,

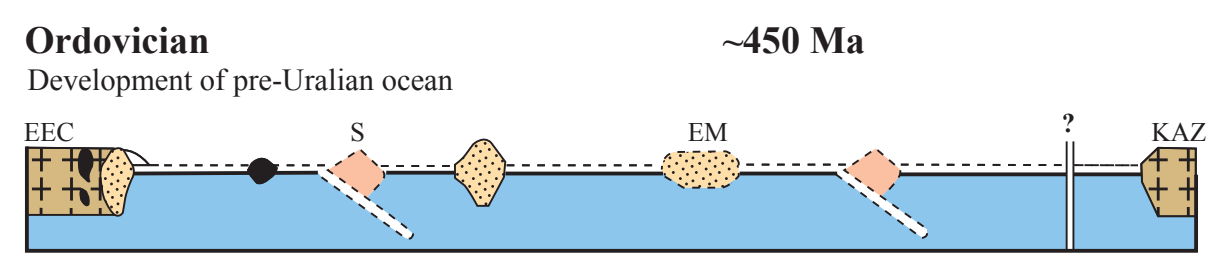

Early Devonian $\quad \sim 410 \mathrm{Ma}$

Initiation of subduction in Magnitogorsk arc

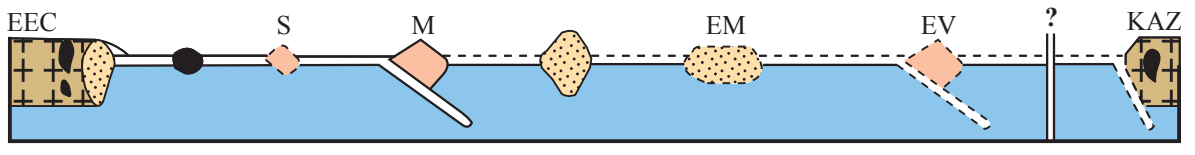

Late Devonian

$\sim 370$ Ma

'Soft collision,' accreted terrane(s) at thinned edge of EEC subducts beneath the Magnitogorsk arc

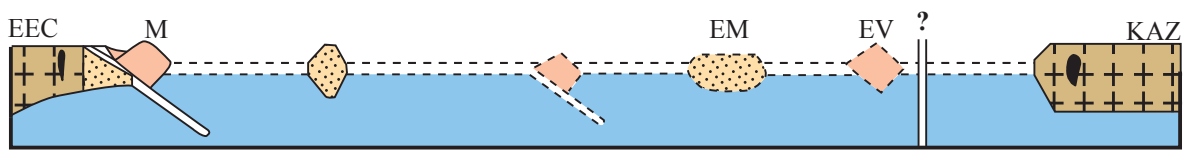

Late Carboniferous-Permian

$\sim 300$ Мa-280 Мa

'Hard collision,' Kazakhstan (and Siberian) cratons approach the EEC

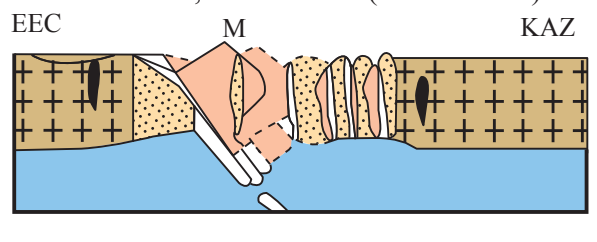

PUM WU UT TM EU TU

Figure 4. Diagram showing tectonic evolution of the southern part of the Uralian orogenic belt along the western margin of the West Siberian Basin Province, Russia. Similar to this example, the convergence of multiple island arcs, continental arcs, micro-continents, and ophiolites resulted in a mosaic of sutured-rock assemblages that now form the basement of the West Siberian Basin, which was a zone of crustal weakness. EEC, East European craton; S, Sakmara island arc; EM, East Mugodzhary micro-continent; KAZ, Kazakh craton; M, Magnitogorsk island arc; EV, East Uralian volcanic subzone; PUM, pre-Uralian marginal depression; WU, West Uralian zone; UT, Ural-Tau zone; TM, Tagil-Magnitogorsk zone; EU, East Uralian zone; TU, TransUralian zone; Ma, million years ago. Modified from Scarrow and others (2002). 


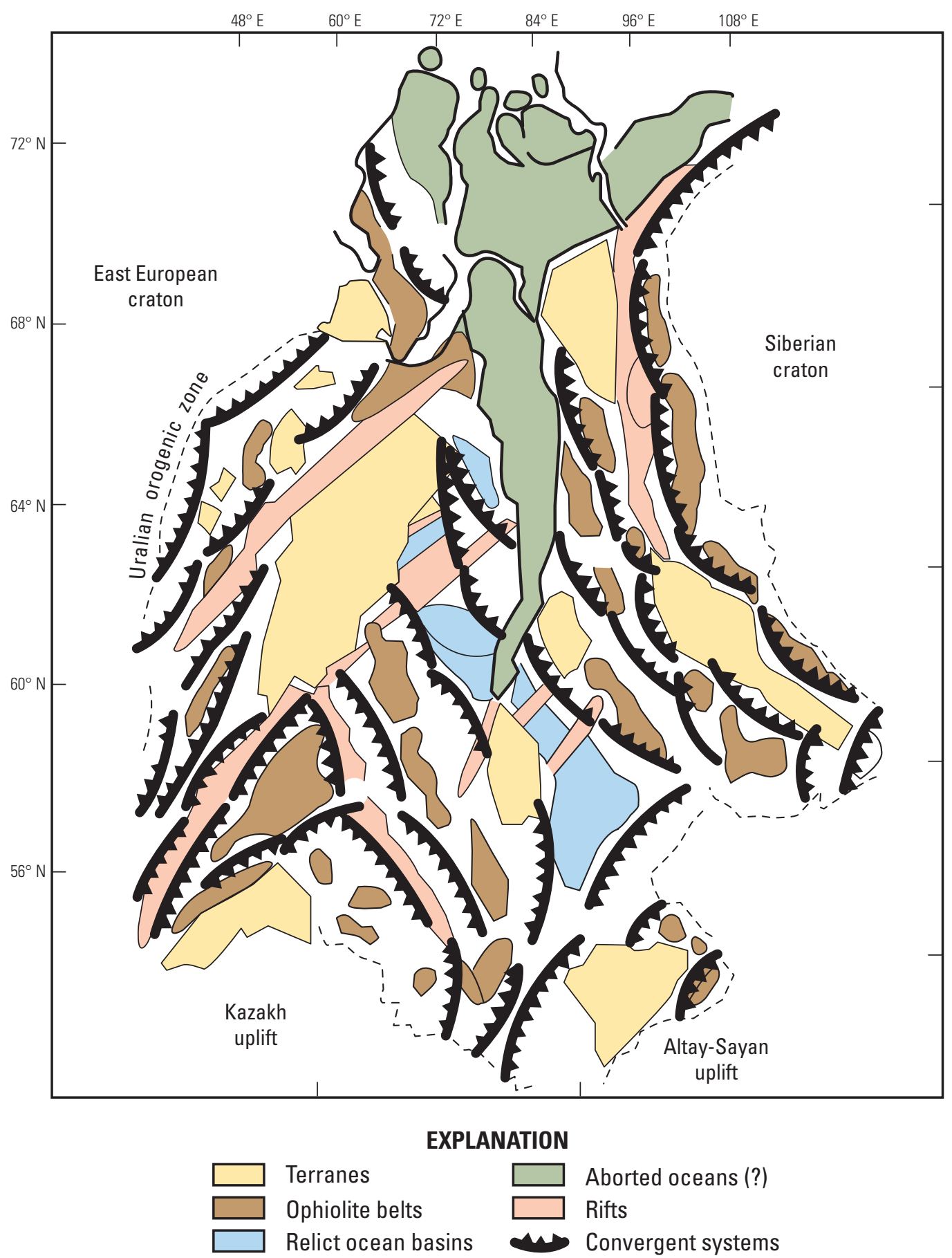

Figure 5. Schematic illustration of the complex heterogeneous basement of the West Siberian Basin Province. Basement is largely an amalgamation of convergent-margin elements such as island arcs and continental arcs, sutures, rifts, ophiolites, and micro-continents. The basement became a coherent entity in the Permian, but the inherent weakness resulted in the focus of Triassic extension. Modified from Aplonov (1995). Dashed line shows general basin boundary from Aplonov (1995). 
was interpreted to have formed as a northwest-directed thinskinned fold-and-thrust belt in Triassic or earliest Jurassic time (Otto and Bailey, 1995; Puchkov, 2009; Scott and others, 2010), which apparently was coeval with extension in the basement of the South Kara Sea area (fig. 1). The motion of the Novaya Zemlya fold belt was accommodated along regional bounding faults (Otto and Bailey, 1995; Görz and Hielscher, 2010).

Following the ultimate closure of the various oceanic basins between the Uralian orogenic belt and terranes in the late Carboniferous and early Permian, the area of the West Siberian Basin apparently was emergent, as there are no preserved Permian sediments (Friberg and others, 2002; Saunders and others, 2005). The evolution of the West Siberian Basin began with volcanism, uplift, extension, and rifting in the latest Permian and Early Triassic, all of which are interpreted to record the regional effects of a possible mantle plume (Saunders and others, 2005; Reichow and others, 2005; Holt and others, 2012). The impact point of the mantle plume is interpreted to be the site of a rift triple junction in the northern part of the basin (Allen and others, 2006). As the head of the mantle plume rose, impacted, and spread beneath the relatively weaker basement, the addition of volcanics and the associated elevated-heat regime resulted in uplift, rifting, erosion, and subaerial emplacement of widespread volcanics (Reichow and others, 2005; Saunders and others, 2005; Allen and others, 2006). Volcanics were emplaced in two phases, at the Permian-Triassic boundary and in the Early Triassic (Ivanov and others, 2013). In the model developed by Allen and others (2006), Permian-Triassic rifting was related to right-lateral oblique extension between the Siberian craton and the East European-Uralian craton in the west (Allen and others, 2006); this was apparently associated with a 30-degree clockwise rotation of Siberia (Puchkov, 2009) at the time of emplacement of the Siberian volcanics.

Regional strike-slip faults that offset basement elements are important features of the West Siberian Basin (Riggasi, 1986; Igoshkin and others, 2008; Gogonenkov, 2009; Görz and Hielscher, 2010), and the transpressional aspect of the fault motion might have been important for structural modifications to many of the hydrocarbon-bearing structures in the basin. The timing of the dextral movement is variously interpreted from having occurred throughout the Mesozoic and Cenozoic (Rigassi, 1986), to being relatively young movement, that occurred mainly in the late Paleogene (Vyssotski and others, 2006). Late Paleogene faulting might have caused reactivation of previously active normal faults prevalent in the basin. The largest of these faults offsets the basement and juxtaposes a dominantly Paleozoic basement on the west with a dominantly Triassic basement in the northeast (Igoshkin and others, 2008).

Rifts of Permian-Triassic age are more pronounced in the northern part of the basin than in the south (Vyssotski and others, 2006; Cherepanova and others, 2013), and these rifts are partly to completely filled with Siberian-age volcanics (Permian-Triassic) (Ivanov and others, 2013). The Siberian volcanics were largely emplaced subaerially, indicating that the West Siberian Basin had not yet formed (Holt and others, 2012). The rifts and various rock assemblages forming heterogeneous basement led to paleotopography in excess of 2 km (Aplonov, 1995; Saunders and others, 2005; Igoshkin and others, 2008), which was critical for the subsequent structural traps in this basin (Ulmishek, 2003). During the synrift phase (Triassic to Callovian), deposition of both volcanics and sediments was largely restricted to rift areas.

By Early to Middle Jurassic time, decay of the thermal regime associated with the Siberian mantle plume resulted in initiation of regional subsidence and the creation of accommodation space, forming the West Siberian Basin (Holt and others, 2012). The first basinwide transgression occurred in the postrift phase, beginning in the Middle Jurassic (Callovian) (Ulmishek, 2003). The $2 \mathrm{~km}$ of basement topography were largely filled in by Late Jurassic time with mostly nonmarine clastic sediments of the Tyumen Formation and marine sediments of the Vasyugan Formation to the north (fig. 6). In Late Jurassic to earliest Cretaceous time (Volgian to Berriasian), the first major rock unit to be deposited across the basin consisted of organic-rich shales of the Bazhenov Formation, representing a basinwide anoxic event recorded as a condensed section (Vyssotski and others, 2006).

During the postrift phase from the Middle Jurassic to the Miocene, sedimentation continued to be strongly influenced by regional base-level changes, and stratigraphic units covered both the rifts and the interrift highs. In the Neocomian (Early Cretaceous), multiple progradations of clinoform deposits of the Achimov Formation were sourced from the Siberian craton to the east, illustrating uplift of the margin of the craton (fig. $7 B$ ). Sedimentation continued to be reflected in transgressive regressive cycles throughout the Mesozoic and into the Cenozoic. The Mesozoic-Cenozoic sedimentary section increases from a total of about 3 to $5 \mathrm{~km}$ in the south to more than $15 \mathrm{~km}$ in the South Kara Sea area (Allen and others, 2006; Cherepanova and others, 2013).

Although the postrift period was dominated by baselevel controlled sedimentation, there was growth of structures, mainly as differential uplift of the interrift highs. Thinning of stratigraphic units across the interrift highs led James (1995) to conclude that the Cretaceous was a time of structural growth, relatively more robust in the Berriasian to Aptian, and Turonian to Campanian, and with slower growth during the Aptian to Cenomanian. Similar phases of structural growth were summarized by Matusevich and others (1997). Malyshev and others (2011) also suggest that a Late JurassicEarly Cretaceous phase of structural growth was significant. The ultimate cause of this Jurassic and Cretaceous structural growth is not known (James, 1995).

The postrift stratigraphic units that extend across the interrift highs exhibit draping across these structures, and draping appears to be a combination of compaction and structural growth. The draping effect is most pronounced in Upper Jurassic units, and this effect commonly decreases in 


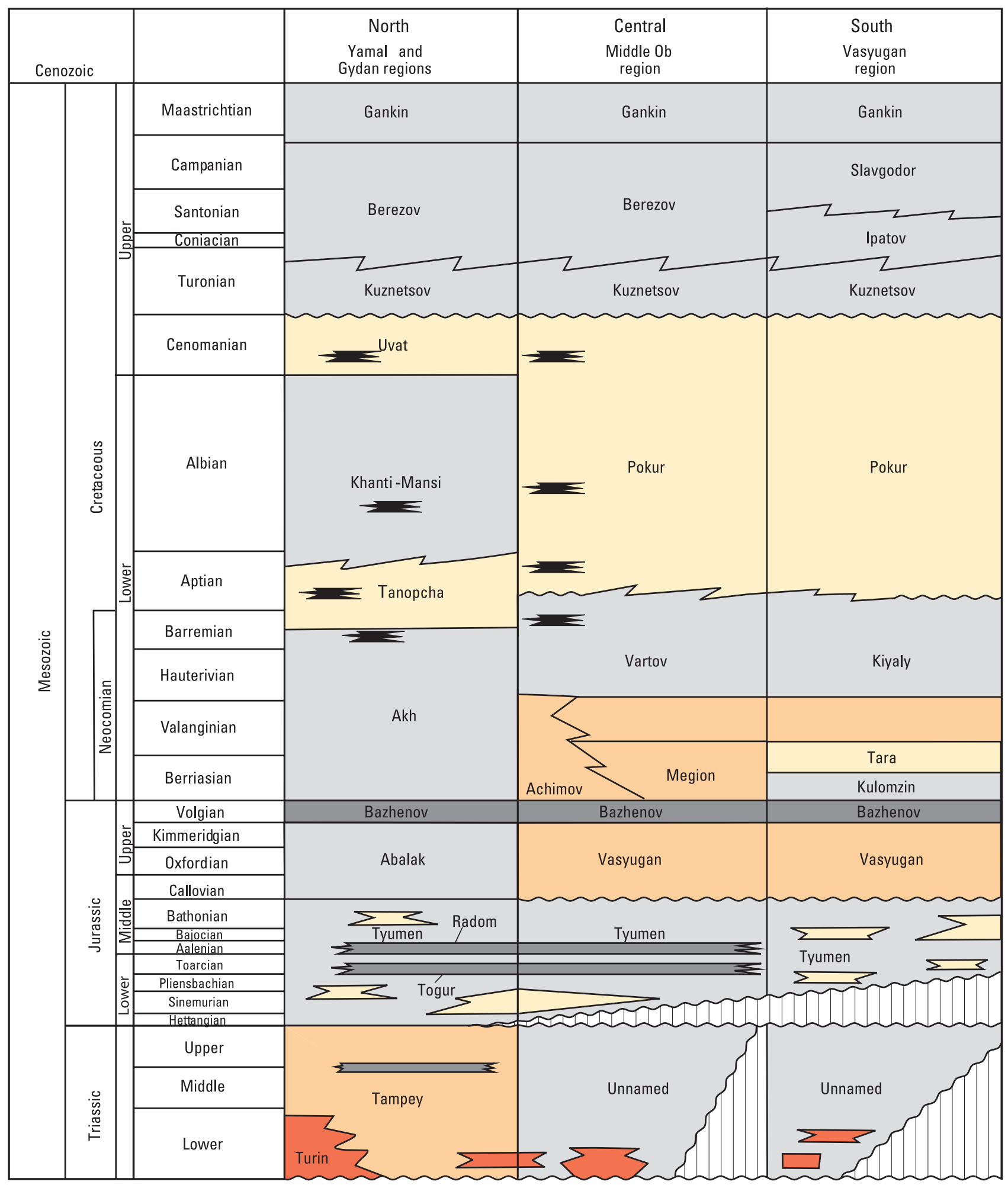

\section{EXPLANATION}

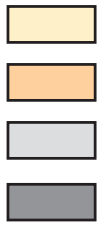

Sandstone

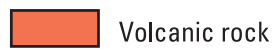

Sandstone and shale

$\sim$ Unconformity

Mainly shale

Organic-rich siliceous shale $\geq \equiv$ Coal

$<$ Gradational contact
Figure 6. Stratigraphic column for the West Siberian Basin Province modified from Ulmishek (2003). This study focuses on the northern and central parts of the West Siberian Basin Province. 
amplitude up section in successively younger stratigraphic units (fig. 7), although this is not a universal e fect.

The overall pattern of base-level controlled sedimentation throughout the basin continued until the late Paleogene, when the West Siberian Basin underwent a phase of uplift, erosion, and compression (or transpression), which appears to be more pronounced in the northern part of the basin. The well-known unconformity at the base of the Neogene in the West Siberian Basin was a result of this event (James, 1995). This phase of structural deformation appears to be more pronounced than the effects of Cretaceous structural movements (Kontorovich, 2009). This deformation might have been related to far-field effects associated with the collision of India and Eurasia in the Paleogene (Davies and others, 2005; Vyssotski and others, 2006), although there is some debate concerning the timing of compression being younger than Paleogene (Puchkov, 2009). There is also debate that far-field e fects related to the collision of India were not significant for structural growth in the West Siberian Basin (James, 1995).

The Oligocene phase of transpressional deformation was interpreted to have affected the following: (1) development of intrabasinal uplifts, (2) reactivation of basement faults and development of inversion structures, (3) uplift of broad anticlinal structures associated with basinal faults blocks, (4) development and reactivation of subvertical faults and positive flower structures, and (5) inversion of half grabens ( yssotski and others 2006, p. 124). These structural features that formed in the late Paleogene are important in the development of the petroleum system in the northern part of the basin.

In summary, the evolution of the West Siberian Basin is divided into Triassic-Early Jurassic synrift and Middle Jurassic to Paleogene postrift phases. The synrift phase was the time formation of the major extensional structures on weak basement throughout the West Siberian Basin occured. The postrift phase generally involved reactivation or growth and modification of existing structures and basinwide sedimentation related to regional base-level changes. The overall structure of the West Siberian Basin shown in regional cross sections includes rifted basement, the decreasing effect of the basement structure on successive overlying stratigraphic units, and the continuation of the Mesozoic section to the north beneath the South Kara Sea (fig. 7)

\section{Stratigraphy of the West Siberian Basin Province}

The stratigraphic succession of sedimentary rocks in the West Siberian Basin Province reflects the tectonic history of the area between the Uralian orogenic belt, Kazakh and AltaySayan uplifts, and Siberian craton (fig. 6). Ulmishek (2003) provided a detailed stratigraphy of the West Siberian Basin that is followed in this study. The basement has been described as being composed of metamorphic, metasedimentary, sedimentary, and igneous rocks ranging from Proterozoic to
Carboniferous age, along with two phases of Permian-Triassic Siberian basalts of the Turin series (Ulmishek, 2003). Nonmarine clastics of the Triassic Tampey Formation unconformably overly basement and are found mainly within rifts, which represents typical rift-fill deposits of lacustrine fluvial, deltaic nearshore, and deep-lacustrine sediments (fig. 6). To the north, organic-rich shale facies of the Tampey Formation are viable oil source rocks (Lopatin, 2013). Potential reservoirs may exist within the fluvial and ma ginal lacustrine sandstones, along with a local lacustrine source rock. Continuing the phase of continental deposition, in Early Jurassic time there was widespread deposition of nonmarine, coal-bearing fluvial rocks of the Tyumen Formation. To the north the Tyumen Formation transitions to nearshore marine rocks, and potential reservoirs exist in marine sandstones in the upper part of the formation. Incised valley fill sandstones and conglomerates also represent potential reservoirs.

By the end of the Middle Jurassic, thermal relaxation resulted in regional sag and the creation of significant acco modation space, and deposition resulted in basement paleotopography being largely covered, leaving little surface relief. The first regional marine transgression in the West Siberian Basin occurred in the Callovian (fig. 6). To the north, coastal plain and nearshore marine sandstones of the Vasyugan Formation (Pinous and others, 1999) transition to mostly marine shales of the Abalak Formation (fig. 6). Potential reservoirs include nearshore marine and, possibly, shelf sandstones, and if gravity flow processes were operating, there are potential slope and base-of-slope fan sandstones reservoirs. From the Early Jurassic to Aptian, numerous regional base-level changes resulted in extensive systems of incision and valley fill deposits, which are potential reservoirs in la ge areas of the basin (Igoshkin and others, 2008). These incised valley fill sandstones, which form stratigraphic traps, represent an important class of largely unexplored reservoirs.

In the Late Jurassic and earliest Cretaceous (Volgian to earliest Berriasian time, but possibly as young as Hauterivian time; Vyssotski and others, 2006), black, organic-rich shales of the Bazhenov Formation were deposited across the West Siberian Basin (fig. 6), representing an anoxic event recorded as a condensed section. In terms of the evolution of petroleum systems, deposition of black, organic-rich marine shales of the Bazhenov Formation was the single most important event in the history of the basin, as the Bazhenov Formation is widely considered to be the source rock for the majority of hydrocarbons in the world's most prolific oil and gas basin

The ongoing creation of accommodation space in the Neocomian led to the formation and deposition of numerous extensive, west-facing clinoform packages sourced from uplift of the Siberian craton to the east (fig. 1). These spectacular geologic features include a spectrum of potential hydrocarbon reservoirs, such as fluvial, deltaic, shelf-ma gin delta, slope, and basin-floor submarine-fan sandstones. The seismic topset facies are composed of fluvial, deltaic, nearshore marine, and sandstones and shales of the Megion and Vartov Formations. The slope and base-of-slope fan sandstones are 


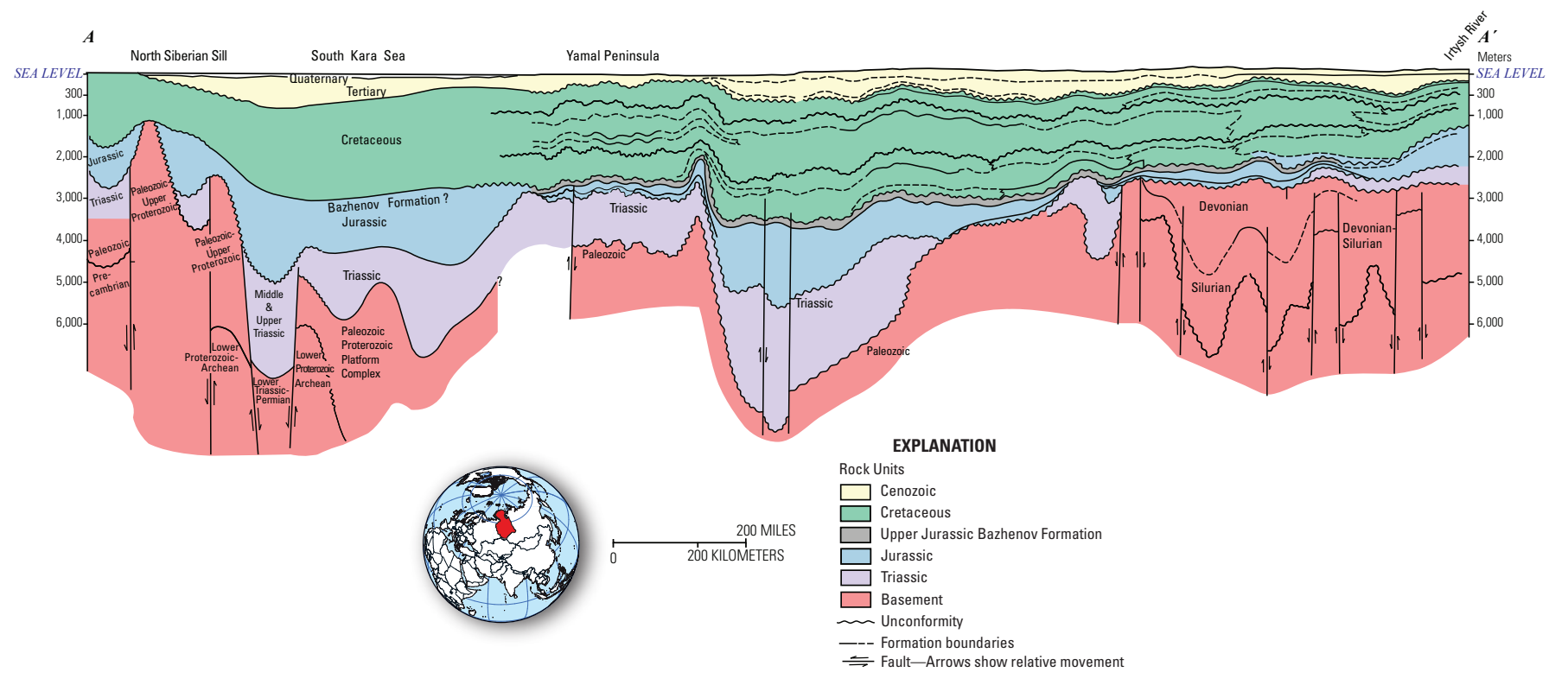

B

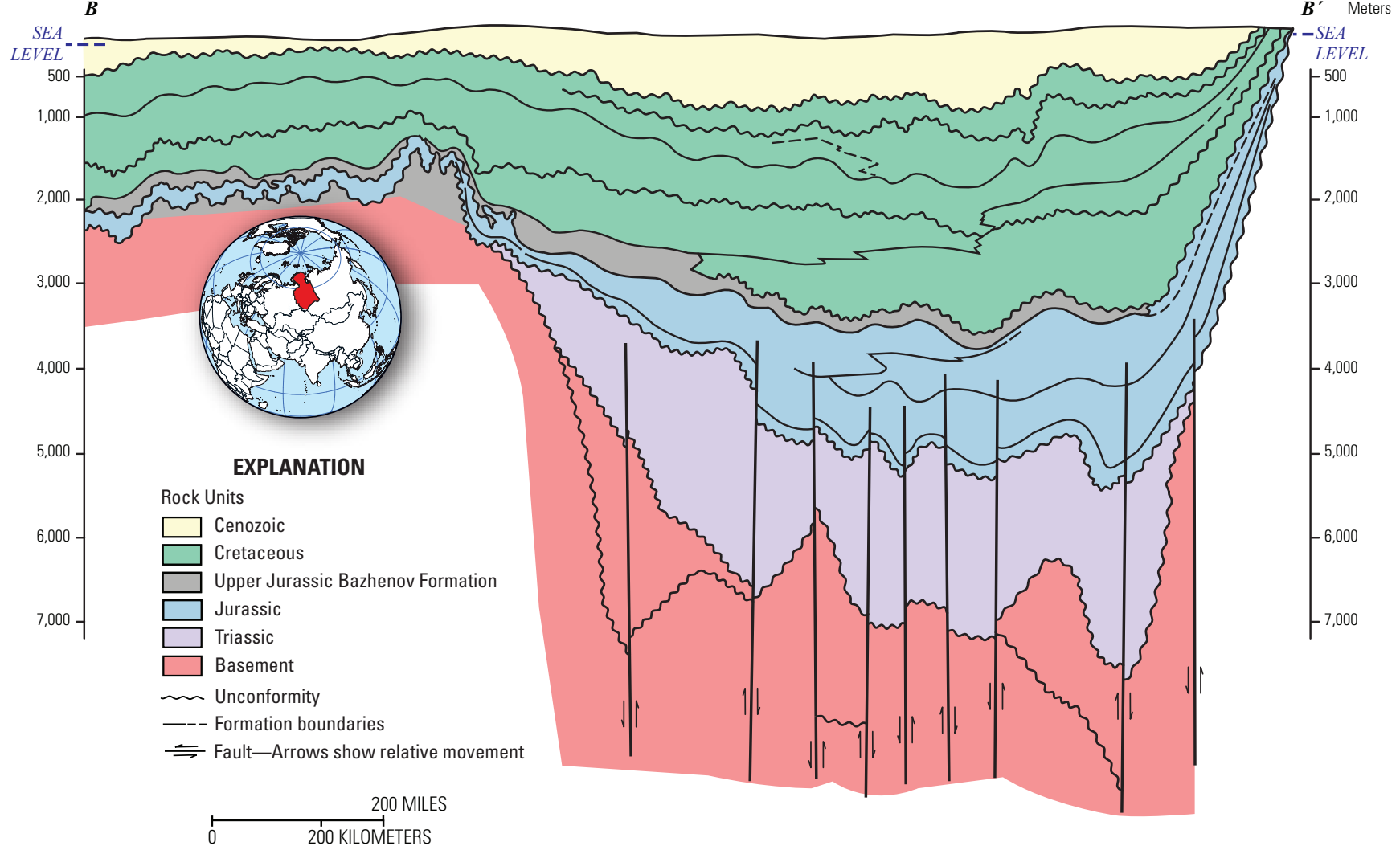

Figure 7. Regional cross sections of the West Siberian Basin Province. Modified from Petersen and Clarke (1989). A, North-south cross section illustrating structurally complex basement, the thick sedimentary section in the poorly studied South Kara Sea area, and the relatively unstructured Mesozoic section. Note that the Upper Jurassic Bazhenov Formation extends across much of the basin. $B$, Southwest-northeast cross section showing complex basement structures and the gradually diminishing effect of the basement structures in successively overlying stratigraphic units. Organic-rich black shales of the Bazhenov Formation are shown as the darker unit. Location of cross sections shown in figure 1. 
known collectively as the Achimov Formation (Pinous and others, 2001). Coeval with the clinoforms are deep water marine shales of the Akh Formation in the north-central part of the basin (fig. 6). The Neocomian clinoform packages are some of the most important oil and gas reservoirs in the basin (Ulmishek, 2003), and remain significant in terms of reservoirs containing undiscovered oil and gas resources.

Following development of the extensive clinoform units, deposition from the Aptian to Cenomanian included thick packages of nearshore marine to shallow marine rocks in the north and west, and fluvial deposits with coals in the east, collectively known as the Pokur Formation (fig. 6). The Pokur Formation has received much attention as the shales and coals in this formation have been widely interpreted as the major source of gas for the northern part of the West Siberian Basin. Fluvial, deltaic, and shallow marine sandstones of the Pokur Formation compose an important set of reservoirs in the basin. From the Turonian to the end of the Cretaceous, deposition of fine-grained clastics was widespread, including siliceous shales of the Kuznetsov, Berezov, and Gankin Formations (fig. 6). These shales, ranging up to $600 \mathrm{~m}$ thick, form an important regional seal to fluid flow across th West Siberian Basin.

From the Oligocene to the middle Pliocene the West Siberian Basin, particularly in the north, underwent uplift, erosion, and compression, leading to additional growth of the Mesozoic arches and anticlinal structures. The amount of uplift and erosion increases to the north, where as much as 2.5 $\mathrm{km}$ of erosion has occured (Igoshkin and others, 2008).

\section{Northern West Siberian Mesozoic Composite Total Petroleum System Description}

The Northern West Siberian Mesozoic Composite Total Petroleum System (TPS) was defined by Ulmishek (2000, 2003) to encompass known and undiscovered oil and gas accumulations in the gas-prone northern part of the West Siberian Basin Province (fig. 8). A composite TPS was defined because the gas could not be positively correlated to any of several potential petroleum source rocks in the Mesozoic section in the northern part of the basin (Ulmishek, 2003). The inability to identify specific source rocks for gas is common and not restricted to the West Siberian Basin, as gases have far less geochemical information to use for correlations than oils.

Potential petroleum source rocks in the Northern West Siberian Mesozoic Composite TPS include organic-rich facies of the nonmarine Triassic Tampey Formation, the nonmarine and marine shales of the Lower to Middle Jurassic Tyumen Formation, lacustrine shales of the Lower Jurassic Togur Formation, marine shales of the Upper Jurassic-Lower Cretaceous Bazhenov Formation, nonmarine organic matter of the Upper Jurassic Vasyugen Formation, and nonmarine shales and coals of the Cretaceous Pokur Formation (fig. 6). Geochemical data and interpretations of the source rock potential of each of these rocks can be found in the following publications: Peters and others (1993, 1994), Kontorovich and others (1997), Hegre and others (1998), Littke and others (1999), Schaefer and others (1999), Ulmishek (2003), and Barboza and others (2007). The source of the majority of oil in the West Siberian Basin is organic-rich shales of the Bazhenov Formation, and secondary sources include the Lower Jurassic Togur Formation, the Tyumen Formation, and the Tampey Formation (Peters and others, 1994; Kontorovich and others, 1997; Ulmishek, 2003; Lopatin, 2013).

The stratigraphic interval of the Bazhenov Formation increases in thickness to the north in the basin, where it is up to $200 \mathrm{~m}$ thick (Vyssotski and others, 2006), compared to $25 \mathrm{~m}$ in the southern part (fig. 9). The total organic-carbon content in the Bazhenov Formation decreases to the north; however, the Bazhenov Formation remains a rich potential source rock with greater than 3 weight percent total organic carbon (TOC) (Kontorovich, 1997; Yuri and others, 2008), despite the possibility of elevated thermal maturities, which would have decreased the measured TOC (fig. $1 \mathrm{~A}$ ). The thermal maturity (as shown by vitrinite reflectance $\left[{ }_{0}\right]$ ) of the Bazhenov Formation quite possibly increases to the north, although there is little maturity data for the South Kara Sea area (fig. $1 B$ ). However, the greater depth of burial would lead to higher thermal maturities in the Bazhenov Formation in the north compared to the southern part of the basin.

The main unresolved resource issue has been the origin of world-class volumes of gas in the northern part of the basin. The origin of gas in the northern part of the West Siberian Basin and the processes responsible for the giant and supergiant gas accumulations have generated an extensive literature with several hypotheses on the origin of gas (summarized by Ulmishek, 2003). Gas is interpreted to have formed through primary biogenic processes, early thermogenic generation, and later thermogenic generation, with nonmarine shales and coals of the Pokur Formation as the main sources (fig. 6). The processes responsible for the accumulation in large structures is variously ascribed to vertical migration of thermogenic gas or lateral migration or long-distance migration of gas dissolved in groundwater.

Early investigations of the geochemistry of gases suggested that the light isotopic signatures led to a hypothesis of a biogenic origin, although the presence of significant volumes of biogenic gas has been questioned (Ulimshek, 2003; Milkov, 2010). The "early thermogenic" gas hypothesis was developed to explain gas potentially sourced from the Cretaceous Pokur Formation (Gavura and Rovenskaya, 2002), which is largely immature with respect to thermal gas generation (Schaefer and others, 1999).

A third hypothesis is that gas in the northern part of the basin originated in the south and was transported to the north along the regional hydrologic gradient as gas dissolved in groundwater (Littke and others, 1999; Cramer and others, 1999). In this hypothesis, an unnamed southern source provided the gas; subsequent uplift in the Neogene caused 


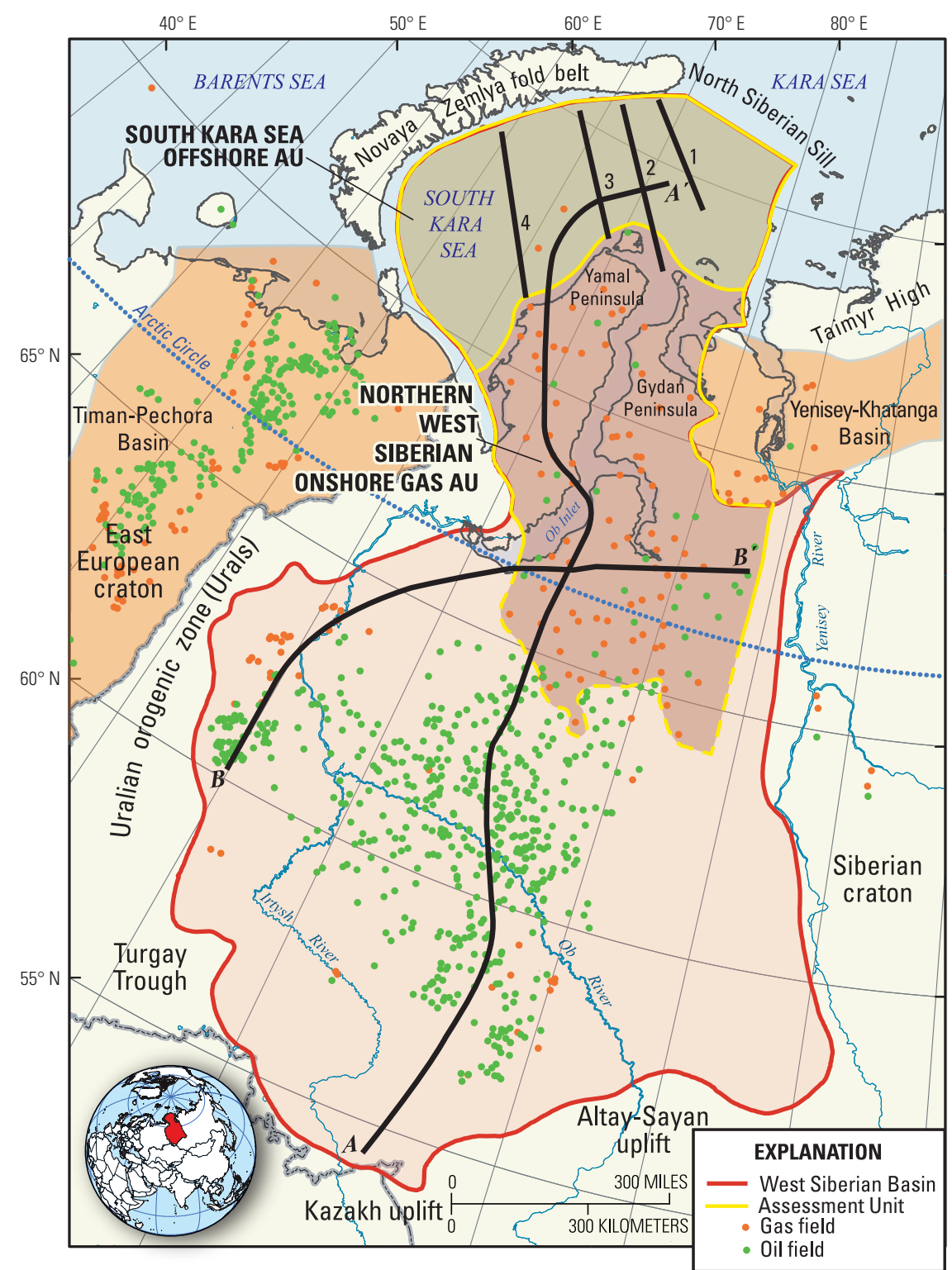

Figure 9. Isopach map showing thickness and extent of the Tithonian to Berriasian section in the West Siberian Basin Province, which is largely organic-rich source rock facies of the Bazhenov Formation. Note that in this interpretation the organicrich source rock facies extends north through much of the South Kara Sea area where it thickens markedly to $200 \mathrm{~m}$ from $25 \mathrm{~m}$ in the central part of the basin. From Vyssotski and others (2006).
Figure 8. Map showing the boundary of the Northern West Siberian Mesozoic Composite Total Petroleum System (TPS) for the northern part of the West Siberian Basin Province (outer yellow line). Boundaries of the South Kara Sea Offshore Assessment Unit (AU) and the Northern West Siberian Onshore Gas AU defined in this study are separated by the inner yellow line. Note that the Northern West Siberian Onshore Gas $\mathrm{AU}$ extends south of the Arctic Circle (blue dotted line). Cross sections are shown in figures 7 and 15 .

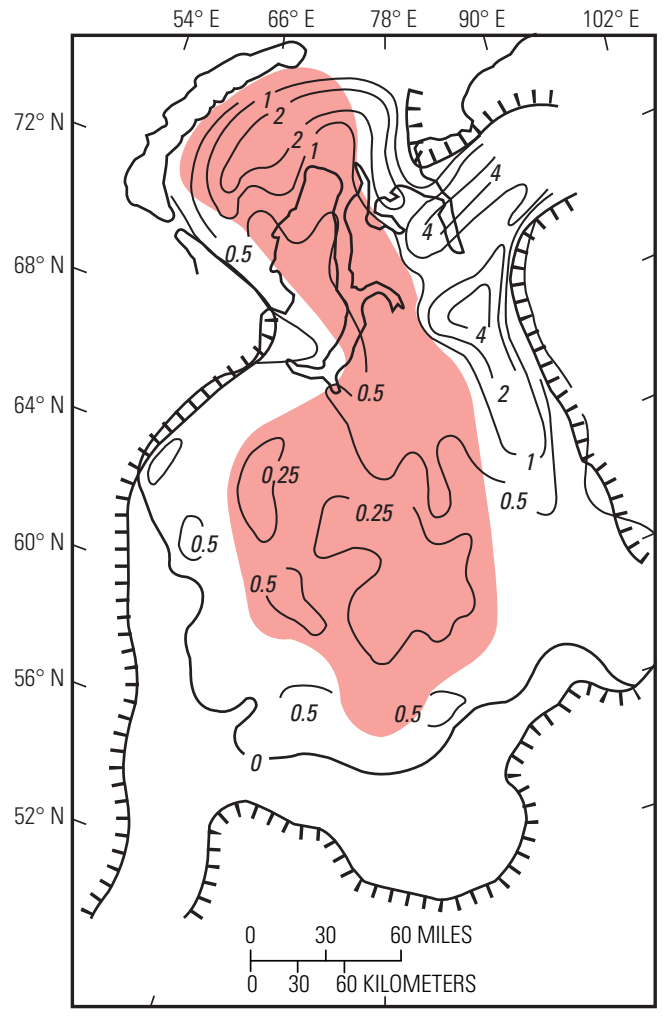

\section{EXPLANATION}

Tithonian-Lower Berriasian potential source rock facies

- 0.5 - Isopach, hundreds of meters لעل Basin boundary 


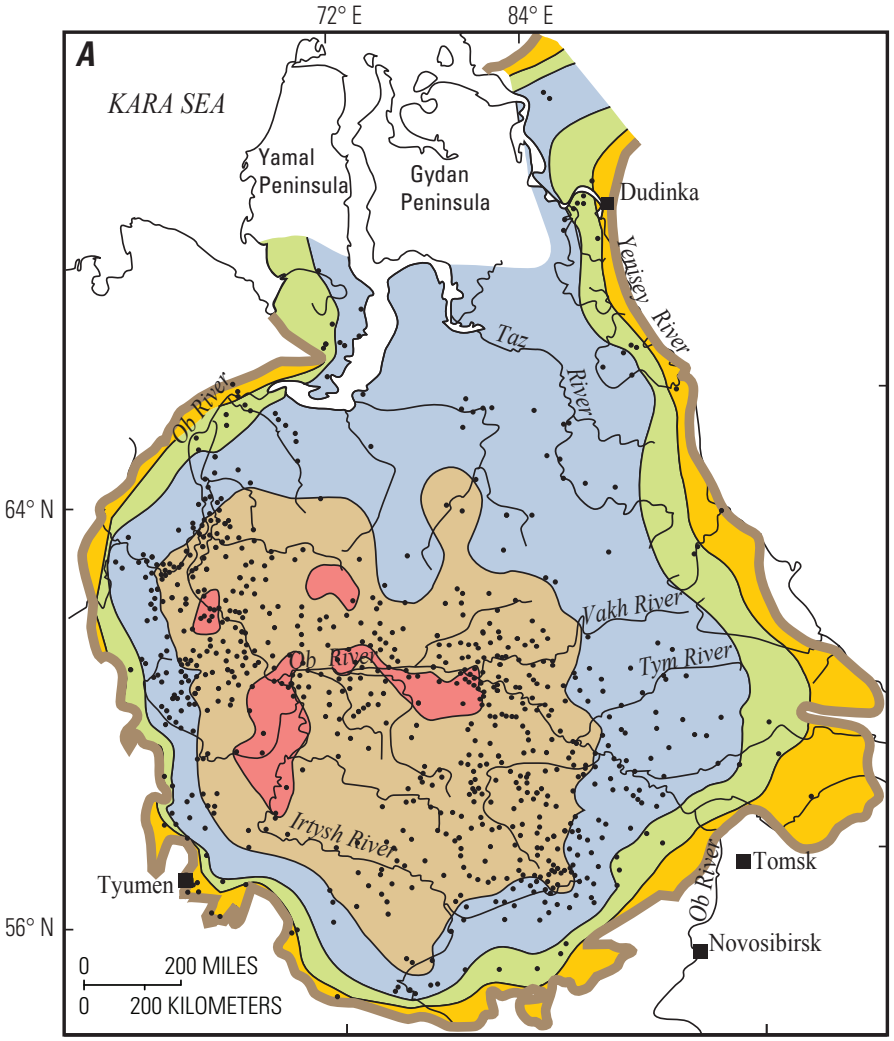

EXPLANATION

TOC content, in weight percent

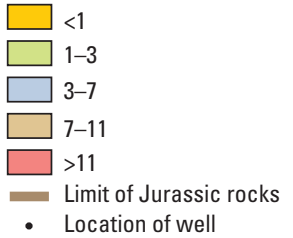

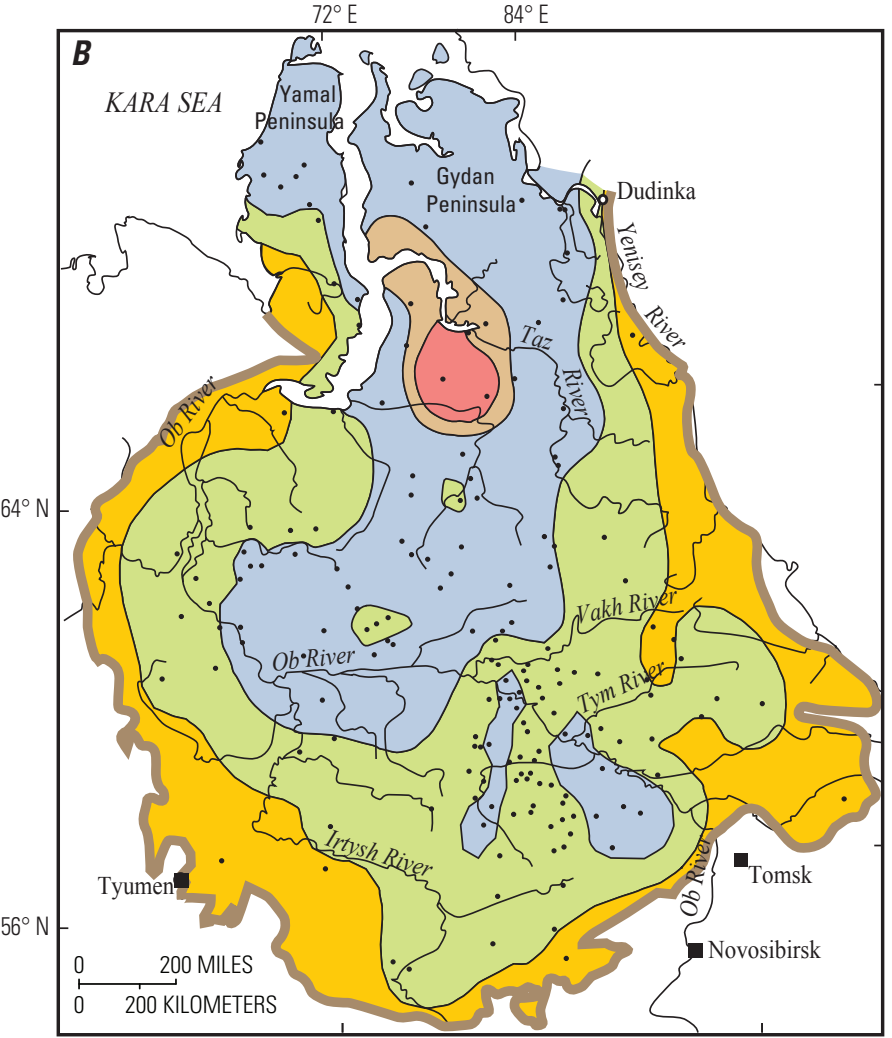

\section{EXPLANATION}

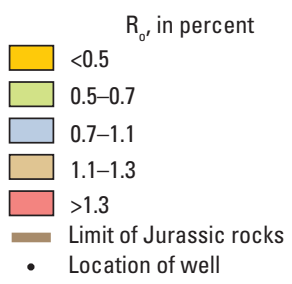

Figure 10. Maps of Total Organic Carbon (TOC) and thermal maturity (vitrinite reflectance, Ro) of the Upper Jurassic Bazhenov Formation source rock facies in the West Siberian Basin Province. Modified from Kontorovich and others (1997) and Ulmishek (2003). A, TOC data for the Bazhenov Formation are not available for the northern part of the basin, but the northernmost values are in the range of 3-7 weight percent TOC. B, Much of the Upper Jurassic Bazhenov Formation is interpreted to be in the oil generation window, with data unavailable in the South Kara Sea area. The greater thickness of the sedimentary section in the South Kara Sea area would suggest that the thermal maturity is higher, possibly into the gas generation window.

degassing of the aquifers, gas expansion, and filling of broad, low-amplitude structures.

A recent study on the origin of the gases in northern West Siberian Basin provided evidence that the gases were largely generated from methanogenic biodegradation of oils within reservoirs, rather than by primary gas generation (Milkov, 2010). In this hypothesis, oils were generated by thermogenic processes, mainly from marine shales of the Upper Jurassic Bazhenov Formation in the northern part of the basin, and oil migrated vertically into reservoirs that included widespread Cenomanian sandstones, rather than having been generated from terrestrial organic matter in the Cretaceous Pokur Formation (fig. 1). Vertical migration of oil is considered feasible in these rocks (Ulmishek, 2003). The oils were then partly altered by methanogenic processes to methane, leaving as evidence oil legs (in some fields), residual oil saturations, and biodegraded oils in the northern part of the basin that commonly is described as containing gas and little oil. This process would have transformed the oil within reservoirs in the northern part of the basin to gas caps and gas fields. This hypothesis is intriguing as it appears to explain the residual oils and oil legs in some fields, the biodegraded oils, and the reliance on a local source rock, and does not require longdistance migration of gas from an unnamed source rock in the southern part of the basin.

With more than $15 \mathrm{~km}$ of Mesozoic sediments in the northern part of the West Siberian Basin (Leonard and others, 2001; Savchenko and others, 2009), it is possible that thermogenic gas was generated from cracking of Bazhenov and other oils (Murris, 2001; Katz and others, 2002), such as oils from marine black-shale facies of the Radom Formation and the Tampey Formation (fig. 6; Lopatin, 2013). This process occurs 


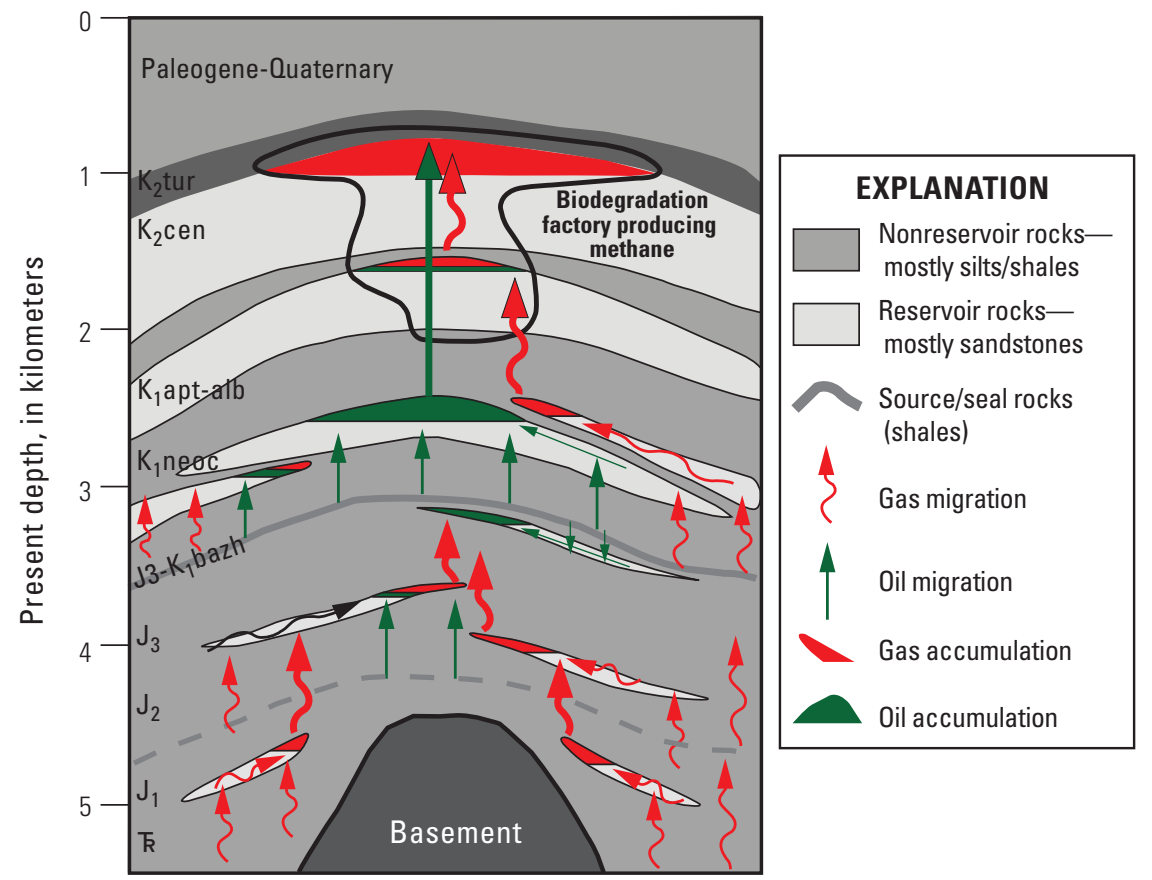

Figure 11. Geologic model for the definition and development of the Northern West Siberian Mesozoic Composite Total Petroleum System. In this model, which is one of several proposed in this basin, the majority of the gas was formed as a result of biodegradation of oil to gas. This process began with the maturation of organic-rich shales of the Bazhenov Formation and possibly other source rocks, leading to oil generation, expulsion, and trapping in structures. The oil was then degraded into gas. $k$, Triassic; $J_{1}$, Lower Jurassic; $J_{2^{\prime}}$ Middle Jurassic; $J_{3^{\prime}}$ Upper Jurassic; $\mathrm{J}_{3}-\mathrm{K}_{1}$ bazh, Bazhenov Formation; $\mathrm{K}_{1}$ neoc, Neocomian; $K_{1}$ apt-alb, Lower Cretaceous Aptian-Albian; $K_{2}$ cen, Upper Cretaceous Cenomanian; $\mathrm{K}_{2}$ tur, Upper Cretaceous Turonian. Modified from Milkov (2010). at vitrinite reflectance values of about 1.6 percent, and, given the burial depths in the northern part of the basin, thermal cracking of oil was certainly possible.

Gas could have been generated at some point in this vast basin by any or all of these proposed processes. Variations in isotopic signatures, chemistry of condensates, and the distribution of fluids are probably not explained by any single process

For this assessment, the Northern West Siberian Mesozoic Composite TPS is defined using ideas summarized from previous studies, with the caveat that the origin of West Siberian gas is still largely hypothetical. In this study, gases are assumed to have been largely generated from secondary biologic processes acting upon Upper Jurassic-sourced oil in Cretaceous and possibly Jurassic reservoirs and by thermal cracking of oil. The oils were largely generated, expelled, and migrated from the Upper Jurassic Bazhenov Formation and possibly other source rocks. Gas generated by biologic degradation of oils within reservoirs formed gas caps and gas fields, in some cases resulting in giant and supe giant fields, with a range of remnant oil legs and residual oils in these reservoirs. The Northern West Siberian Mesozoic Composite TPS includes the possibility for significant undiscovered resources, particularly in the South Kara Sea Offshore Assessment Unit, where there has been little exploration compared to the onshore part of the West Siberian Basin.

\section{Timing of Thermal Maturation}

Timing of source rock maturation involves an estimation of when a petroleum source rock attained a sufficient thermal exposure for oil and gas generation. In a basin of this scale with widespread source rocks, it is difficult to specify when generation began. For the organic-rich shales of the Bazhenov Formation in the West Siberian Basin, generation of oil began in the Albian and was completed by the Eocene (Ulmishek, 2003). This maturation period reflects oil generation, migr tion, and entrapment in updip or overlying reservoirs, generalized for the entire basin. Kontorovich and others (1997) provide burial history curves from several specific areas in the basin, and these curves illustrate the variation in the timing of oil generation from the main source rocks. Galushkin and others (1999) show two burial history curves from the Urengoy Field that place the Bazhenov Formation in the oil generation window, and the Tyumen Formation largely in the gas window. As the Mesozoic section in the northern part of the basin is thicker and deeper, the Tyumen, Bazhenov, and other source rocks could be within the gas generation window in the northern part of the basin. Fomin and others (2007) concluded thermal maturity of Triassic and Jurassic rocks increases to the north, so that these rocks are all within the gas generation window. It is possible that some of the gas in the northern part of the basin originated from deep thermogenic processes, including oil cracking (Murris, 2001; Milkov, 2010), and the timing may or may not be related to the tectonic event in the late Paleogene.

The processes responsible for biodegradation of oil, as hypothesized by Milkov (2010), presumably occurred along with late Paleogene uplift and structural reactivation as the oils were brought up into the cooler part of the section, allowing biologic processes to operate on the crude oils. The timing of these processes was not specifically discussed in Milkov (2010) - and they are not necessarily tied temporally to uplift—only that the oils needed to be in a thermally cooler part of the section for the effective operation of biologic processes. 


\section{Assessment Unit Descriptions}

The two assessment units (AU) described and assessed in this study were adopted from an earlier USGS oil and gas assessment of the West Siberian Basin Province (Ulmishek, 2000; 2003). As these AUs are north of or are partially above the Arctic Circle they were reassessed for the USGS 2008 Circum-Arctic Oil and Gas Resource Appraisal program. These AUs fall entirely within the Northern West Siberian Mesozoic Composite TPS boundary (fig. 8)

\section{Northern West Siberian Onshore Gas AU Description}

The Northern West Siberian Onshore Gas AU encompasses all potential oil and gas reservoirs in structural and stratigraphic traps within the onshore portion of the Northern West Siberian Mesozoic Composite TPS (fig. 8). The area of the AU is about $582,000 \mathrm{~km}^{2}$. This AU extends to the southern TPS boundary, south of the Arctic Circle.

\section{Geologic Model for Assessment}

The geologic model for this assessment is for oil generated from Mesozoic source rocks (mainly the Upper JurassicLower Cretaceous Bazhenov Formation) to have migrated vertically and updip into structural traps associated with paleotopography on complexly structured and rifted basement, or into stratigraphic traps within rifts, Neocomian clinoforms, and incised valleys. Oils were then biologically degraded and transformed, ultimately, into gas, which filled the structures and stratigraphic traps, possibly assisted by late Cenozoic uplift and gas expansion. In this model, oils were also thermally cracked to gas, because source rocks in this part of the basin are within the thermal window for gas. Reservoirs are mainly Jurassic-to-Cenomanian siliciclastic reservoirs that underlie a regional Turonian shale seal. Potential reservoirs include fluvial-deltaic to nearshore lacustrine sandstones in rifts, fluvial to estuarine sandstones in incised valleys, and fluvial to deep marine sandstones associated with clinoforms. Although labeled as a gas AU, there is significant potential for undiscovered oil resources. The largest structures have most likely been tested in this AU, but few tests have been made of stratigraphic traps. The potential exists for deep reservoirs as few deep prospects have been tested. The petroleum system events chart for this AU is in figure 12. The age ranges for petroleum generation, migration, and accumulation reflect considerable uncertainty.

\section{Geological Analysis of AU Probability}

Charge Probability.-Several potential petroleum source rocks reached sufficient thermal maturation to have gene ated and expelled petroleum in this AU; these include the

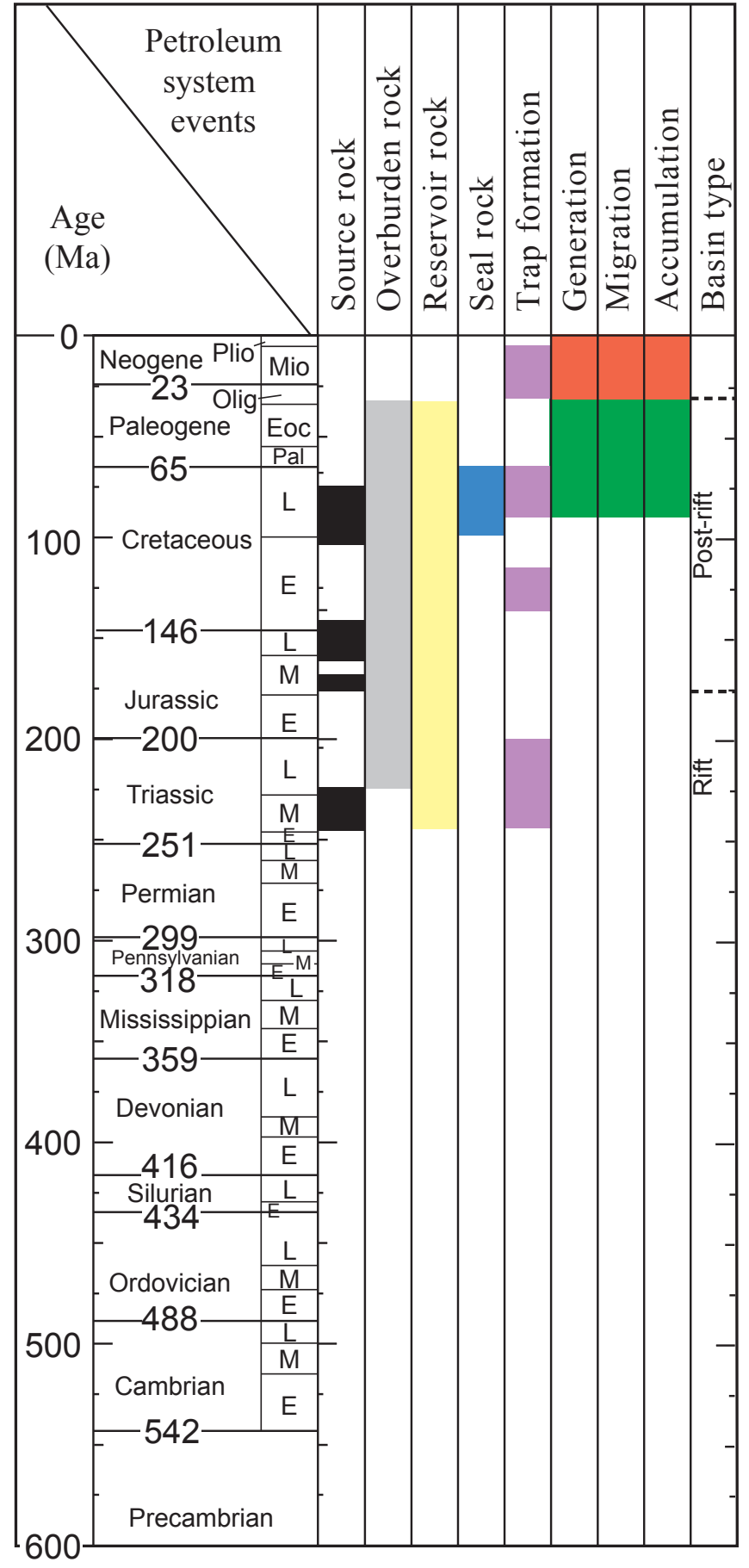

Figure 12. Total petroleum system events chart for the Northern West Siberian Onshore Gas Assessment Unit. For the Generation, Migration, and Accumulation categories, green represents oil, and red represents gas. Ma, million years ago; Plio, Pliocene; Mio, Miocene; Olig, Oligocene; Eoc, Eocene; Pal, Paleocene; L, Late; M, Middle; E, Early. 
organic-rich marine shales of the Upper Jurassic Bazhenov Formation (Ulmishek, 2003). Given that more than 80 fields are greater than minimum size (fig. 13; 50 million barrels of oil equivalent [MMBOE]), the probability for the occurrence of 1 more oil or gas field of minimum size (50 MMBOE) is estimated to be 100 percent, or 1.0.

Rocks Probability.-The oil and gas discoveries greater than minimum size from this AU reported by 2006, in reservoirs mainly of Cretaceous age, demonstrate that reservoir quality is not a source of geologic risk. Potential reservoirs range from siliciclastic fluvial-deltaic, nearshore marine, shelf, and slope-to-fan sandstones, and range from Jurassic to Cretaceous in age. Seals are provided by regional Turonian shales. The probability of the presence of adequate reservoir and seal rocks for a field of minimum size is estimated to be 100 percent, or 1.0 .

Timing and Preservation Probability. - Given that more than 80 oil and gas fields greater than minimum size have been discovered in this AU by 2006 (IHS Energy, 2007), timing and preservation are not considered to be a source of geologic risk for the presence of 1 more undiscovered field of minimum size. Although it is likely that the majority of structures in this AU were subsequently reactivated during the late Paleogene compressional event, this process does not appear to have had a detrimental effect on the trapping and preservation of petroleum. Timing would also have been adequate for the preservation of petroleum in stratigraphic traps (Ulmishek, 2003). The overall geologic probability is the product of the three geologic probabilities, or 1.0. This indicates that there is a 100 percent chance that at least one undiscovered oil or gas field of minimum size (50 MMBOE) is present in this AU.

\section{Geologic Analogs for Assessment Input}

The assessment of the Northern West Siberian Onshore Gas AU used sizes and numbers of existing fields (IHS Energy, 2007) to estimate sizes and numbers of undiscovered fields, so analogs were not necessary for this part of the analysis. The co-product ratios and ancillary data were based largely on data from existing fields in the AU and, where necessary, from the World Averages Analog Set (Charpentier and others, 2008). The assessment input data are summarized in Appendix 1.

Numbers of Undiscovered Fields.-The distribution of numbers of undiscovered oil and gas fields is based on an analysis of known fields in this AU (fig. 13). Given that about 21 oil fields greater than minimum size (50 MMBOE) have been discovered in this $\mathrm{AU}$, and given the discovery history (fig. $1 \mathrm{~A}$ ), the number of undiscovered oil fields is estimated to be 8 fields at the median, with a minimum of 1 and a max mum of 64 oil fields. For gas fields, given that there are 6 known gas fields above the minimum size of 300 billion cubic feet of gas (BCFG) and given the discovery history (fig. $1 B$ ), the number of undiscovered gas fields was estimated to be 24 at the median, with a minimum of 1 and a maximum of 144 gas fields
An analysis of existing fields indicates that petroleum fluids in this AU contain more gas than oil, and the mode of the oil/gas mix was determined to be 25 percent oil, with a minimum of 10 percent and a maximum of 40 percent, reflec ing the uncertainty. This distribution of oil/gas mix was used to estimate zero oil fields at the minimum, 8 oil fields at th median, and 64 oil fields at the maximum, 1 gas field at th minimum, 24 gas fields at the median, and 144 gas fields at th maximum (Appendix 1).

Sizes of Undiscovered Fields. - Sizes of undiscovered oil and gas fields were estimated using the discovery history of sizes of existing fields in this AU. An analysis of grown oil field sizes (fig. $1 \mathrm{~A}$ ) strongly suggests that the largest oil field has already been discovered in this AU, given that the discovery process generally shows that as exploration proceeds, sizes of subsequently discovered fields decrease with time. The median size of undiscovered oil fields is estimated to be about 10 million barrels of oil (MMBO) given the median sizes of discovered fields greater than 50 MMBO. Similarl, the largest gas field has likely already been discovered, based on the discovery history data. Median undiscovered gas field size was estimated to be $660 \mathrm{BCFG}$.

The maximum oil field size (at zero probability) was estimated using an analysis of the sizes of discovered fields. The largest expected oil field was estimated to be about 430 MMBO given the discovery history, and this led to an estimated size of about 2,000 MMBO at zero probability. Thus, the distribution of undiscovered oil field sizes is $50 \mathrm{MMBO}$ at the minimum, $80 \mathrm{MMBO}$ at the median, and 2,000 $\mathrm{MMBO}$ at the maximum of zero probability. The "largest expected gas field" was estimated to be about 5,500 BCFG given the discovery history, which led to an estimate of about 20,000 BCFG for the maximum gas field size at zero probabilit . In summary, the distribution of sizes of undiscovered gas fields is $300 \mathrm{BCFG}$ at the minimum, 660 BCFG at the median, and 20,000 BCFG at the maximum.

Co-Product Ratios and Ancillary Data.-Co-product ratios (gas/oil, natural gas liquids/oil, and liquids/gas) were estimated using discovered oil and gas fields as a guide. The median gas/oil ratio for undiscovered fields was estimated to be 5,500 cubic feet of gas per barrel of oil (CFG/BO), the median natural gas liquids (NGL) to gas ratio was estimated to be 20 barrels of NGL per million cubic feet of gas (BNGL/MMCFG), and the median liquids/gas ratio in undiscovered gas fields was estimated to be 30 barrels of liquids per million cubic feet of gas (BLIQ/MMCFG). Ancillary data were derived from data from existing oil and gas fields (Appendix 1)

Drilling depths for undiscovered fields were estimated from all discovered fields within the AU and from cross sections, and water depths within the AU were estimated from publically available bathymetric maps. Drilling depths for undiscovered oil fields are a minimum of $1,000 \mathrm{~m}$, a median of $2,000 \mathrm{~m}$, and a maximum of $4,000 \mathrm{~m}$. For undiscovered gas fields, drilling depths ranged from a minimum of $1,000 \mathrm{~m}$ to a median of 2,500 m, with a maximum of 5,000 m. Estimates of 

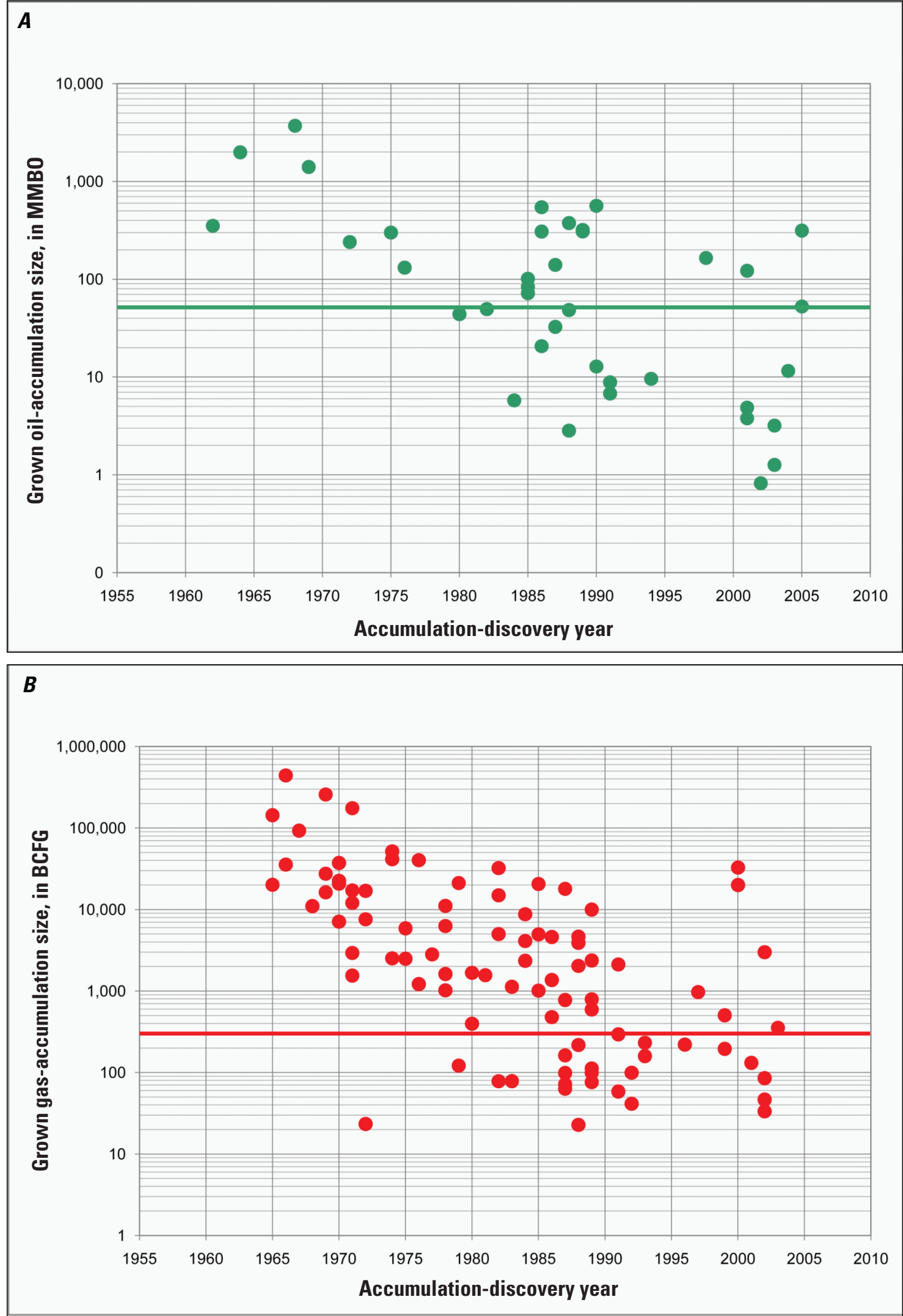

Figure 13. Plot of grown sizes and numbers of oil and gas fields in the Northern West Siberian Onshore Gas Assessment Unit 11740301 (IHS Energy, 2007). A, Sizes of grown oil fields versus discovery year in million barrels of oil (MMBO). $B$, Sizes of grown gas fields versus discovery year in billion cubic feet of gas (BCFG). Green line represents minimum field size for oil and red line represents minimum field size for gas considered in this assessment. 
water depths for undiscovered oil and gas accumulations are a minimum of $0 \mathrm{~m}$, a median of $10 \mathrm{~m}$, and a maximum of $50 \mathrm{~m}$.

\section{South Kara Sea Offshore AU Description}

The South Kara Sea Offshore AU encompasses all conventional reservoirs within the northern part of the West Siberian Basin Province. This AU is bounded to the northwest by the Novaya Zemlya fold belt and to northeast by the Siberian sill; it is bound to the west by the northern Uralian orogenic belt, to the south by the southern boundary of the Northern West Siberian Mesozoic Composite TPS, and to the east by the Taimyr fold belt, the Yenisey-Khatanga Basin, and the Siberian craton (fig. 8). The area of the South Kara Sea Offshore AU is about $310,000 \mathrm{~km}^{2}$. The geologic definition and extent of the AU are the same as those used in the 2000 USGS oil and gas assessment (Ulmishek, 2000, 2003).

This AU is far less explored compared to the Northern West Siberian Onshore Gas AU. The basement in the South Kara Sea area is rifted as in the southern part of the West Siberian Basin, but rifting may be more pronounced in the north than in the south part of the West Siberian Basin (Vyssotski and others, 2006; Cherepanova and others, 2013). A map depicting the largest undrilled prospects indicates that significant potential remains for undiscovered oil and gas in this AU (fig. 14). Structures exhibit the same type of draping and trapping configurations as in the southern part of the West Siberian Basin (fig. 15)

\section{Geologic Model for Assessment}

The geologic model for this assessment is for oil generated from Mesozoic source rocks, mainly the Upper Jurassic Bazhenov Formation, to have migrated vertically and updip into reactivated structural traps associated with paleotopography on complexly structured basement, and also into stratigraphic traps within rifts, clinoforms, and incised valleys. Oils were biologically degraded and transformed ultimately into gas, which filled the la ge broad structures. The gas also could have originated from the thermal cracking of oil in reservoirs. Reservoirs are mainly Upper Jurassic to Cenomanian siliciclastic reservoirs that underlie a regional Turonian shale seal. Potential reservoirs include fluvial-deltaic to nearshore lacustrine sandstones in rifts, fluvial to estuarine sandstones in incised valleys, and fluvial to deep-marine sandstones assoc ated with clinoforms. The exploration history is far less extensive in this AU than in the previous AU because of limited drilling offshore. Many structures and stratigraphic traps are present, of which only a few have been tested. The petroleum system events chart for the South Kara Sea Offshore AU is shown in figure 16. The age ranges for generation, migration, and accumulation indicate considerable geologic uncertainty. Geologic considerations indicate that gas in this AU could have been thermally generated earlier than in the Northern West Siberian Onshore Gas AU.

\section{Geological Analysis of AU Probability}

Charge Probability. - Charge was not considered a source of geologic risk in this AU as several petroleum source rocks are present and sufficient burial occurred for petroleum generation and thermal maturation. The presence of several potential source rocks, particularly the Bazhenov Formation, and at least two giant gas fields discovered with three wildcat wells indicates that there is no risk on charge to form a field of minimum size (50 MMBOE). The charge probability was estimated to be 1.0 .

Rocks Probability.-Most of the potential reservoirs in the Mesozoic section of this AU are in siliciclastic rocks of the Albian-Cenomanian Pokur Formation (fig. 6). The regional Turonian shale provides seals in the siliciclastic section. For these reasons, the probability that there is adequate reservoir rock and seal to form a field of minimum size in this AU is estimated to be 1.0 .

Timing and Preservation Probability.-The compressional structural regime served to mildly invert many of the former rift-related extensional structures (Ulmishek, 2003). Inversion might have caused some fluid re-migration, but this was not considered a source of significant geologic risk. The probability of timing and preservation of petroleum system elements in this AU is estimated to be 1.0. The overall geologic probability is the product of the three geologic probabilities, or 1.0. This indicates that there is a 100 percent chance that an undiscovered oil or gas field of minimum size (50 $\mathrm{MMBOE}$ ) is present in this $\mathrm{AU}$.

\section{Geologic Analogs for Assessment Input}

The Architecture-Rift-Sag Set and Structural SettingCompressional Analog Set (Charpentier and others, 2008) were used to estimate numbers and sizes of undiscovered oil and gas fields given that as of 2006 only two fields greate than minimum assessed size have been found in this AU. In addition, the World Averages Analog Set was used to estimate co-product ratios and ancillary data. The assessment input data for the South Kara Sea Offshore AU is summarized in Appendix 2.

Numbers of Undiscovered Fields.-The median oil and gas field densities from the Structural Setting-Compressional Analog Set and Architecture-Rift-Sag Analog Set were 0.25 fields $/ 1,000 \mathrm{k}^{2}$ and 0.21 fields $/ 1,000 \mathrm{k}^{2}$, respectively. A density of 0.23 fields $/ 1,000 \mathrm{k}^{2}$ was used along with the $\mathrm{AU}$ area of $310,000 \mathrm{~km}^{2}$ to calculate a median number of 72 undiscovered fields, which was decreased by the 2 discovered gas fields, leaving a median estimate of 70 undiscovered oil and gas fields. The maximum number of undiscovered fields was estimated to be 250 , reflecting a mean analog density of 0.405 fields $/ 1,000 \mathrm{k}^{2}$, which was doubled to account for the possibilities for numerous smaller structural and stratigraphic traps. This estimate illustrates the high geologic uncertainty of trap density in the South Kara Sea Offshore AU. Thus, the 


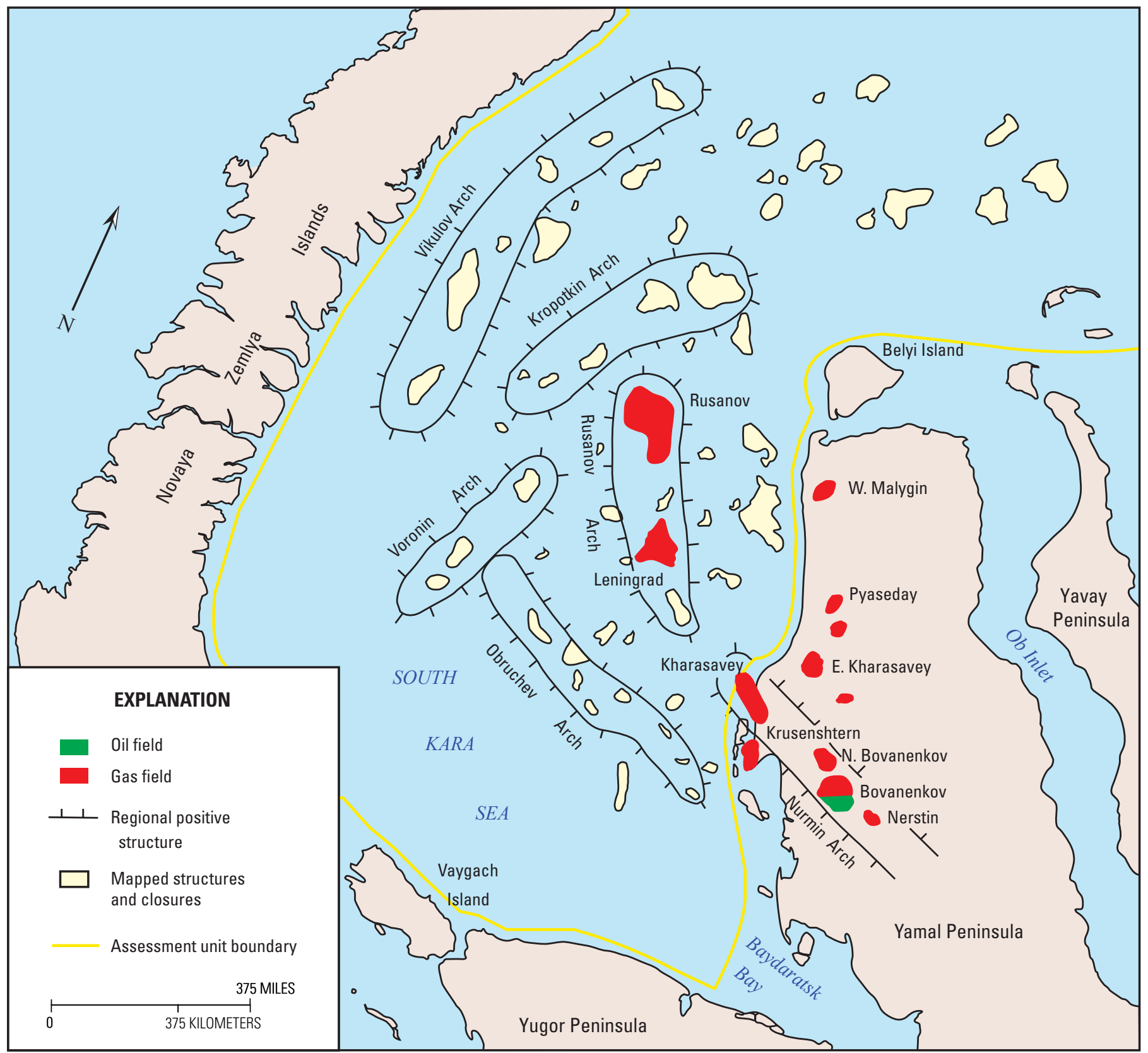

Figure 14. Map of identified prospects and discovered gas fields in part of the South Kara Sea Offshore Assessment Unit. Many of the large structures and closures defined from seismic data in the South Kara Sea remain undrilled and presumably there are numerous smaller structures that have not been mapped. Three exploration wells resulted in the discovery of two giant gas fields. From Ulmishek (2003). 


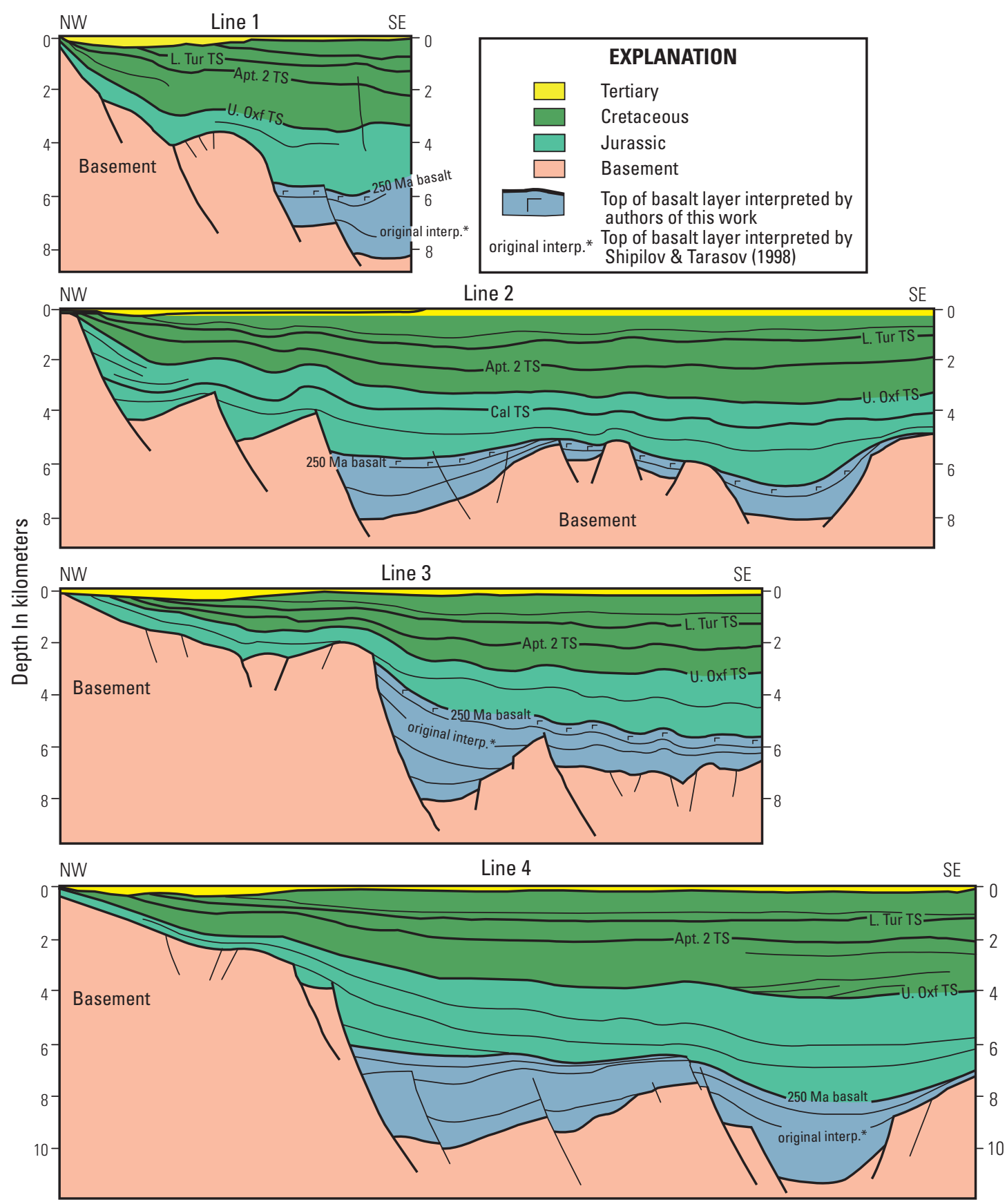

Figure 15. Structural cross sections in the South Kara Sea area illustrating the effect of basement structure on the overlying Mesozoic sedimentary section. Many of these structures in the South Kara Sea Offshore Assessment Unit remain undrilled. Locations of the cross sections are shown in figure 1. Modified from Vyssotski and others (2006). L. Tur TS, Lower Turonian transgressive surface; Apt. 2 TS, Aptian-2 transgressive surface; U. Oxf TS, Upper Oxfordian transgressive surface; Cal TS, Callovian transgressive surface; Ma, million years ago; interp., interpretation. 


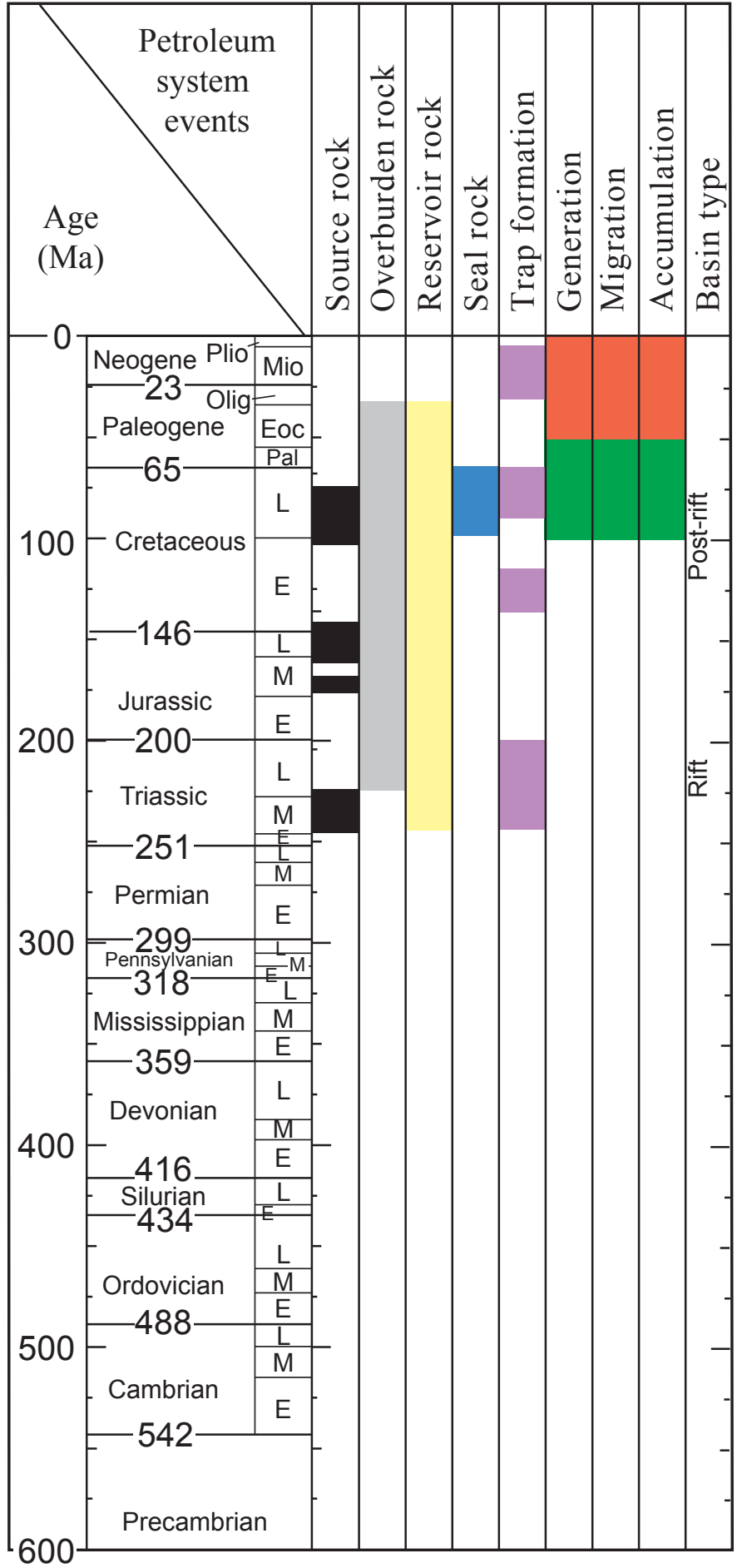

Figure 16. Total petroleum system events chart for the South Kara Sea Offshore Assessment Unit. For the Generation, Migration, and Accumulation categories, green represents oil, and red represents gas. Ma, million years ago; Plio, Pliocene; Mio, Miocene; Olig, Oligocene; Eoc, Eocene; Pal, Paleocene; L, Late; M, Middle; E, Early. distribution of numbers of undiscovered fields is 1 at the min mum, 70 fields at the median, and 250 fields at the maximu

Most of the undiscovered resource in this AU is estimated to be gas, but there is potential for undiscovered oil resources. The minimum and mode of the oil/gas mix were estimated to be 5 percent and 15 percent, respectively, and the maximum was estimated at 25 percent. Using these estimates, the distribution of undiscovered oil fields was calculated to be zero at the minimum, 10 at the median, and 60 at the maximum. For undiscovered gas fields, the minimum was calculated to be 1 field, the median 60 fields, and the maximum 230 fiel (Appendix 2).

Sizes of Undiscovered Fields. - Sizes of undiscovered oil and gas fields were guided by the Structural Setting-Compressional Analog Set and Architecture-Rift-Sag Analog Set. The median oil accumulation size was set at $130 \mathrm{MMBO}$, as that size reflected the median of both analog sets. The largest expected oil field was estimated to be about $700 \mathrm{MMBO}$, and this requires a maximum oil field size of about 3,500 $\mathrm{MMBO}$ at zero probability. Thus, the distribution for sizes is $50 \mathrm{MMBO}$ at the minimum, $130 \mathrm{MMBO}$ at the median, and $3,500 \mathrm{MMBO}$ at the maximum of zero probability. The undiscovered gas field sizes were $300 \mathrm{BCFG}$ at the minimum and $1,400 \mathrm{BCFG}$ at the median. The largest expected gas field was estimated to be about 190,000 BCFG given the exploration immaturity and defined prospects, and this requires a max mum size at zero probability of 800,000 BCFG.

Co-Product Ratios and Ancillary Data.-Co-product ratios were estimated using the co-product ratio summaries in the adjacent Northern West Siberian Onshore Gas AU. Ancillary data were also derived primarily from the Northern West Siberian Onshore Gas AU and were compared to the World Averages Analog Set. The median gas/oil ratio for undiscovered fields was estimated to be 5,500 CFG/BO, the median $\mathrm{NGL} /$ gas ratio was estimated to be $20 \mathrm{BNGL} / \mathrm{MMCFG}$, and the median liquids/gas ratio in undiscovered gas fields was estimated to be $30 \mathrm{BLIQ} / \mathrm{MMCFG}$.

Drilling depths for undiscovered fields in the AU were estimated from published cross sections from the AU; water depths within the AU were estimated from publically available bathymetric maps. Drilling depths for undiscovered oil fields ranged from a minimum of $1,000 \mathrm{~m}$ to a median of 2,000 m, and a maximum of 4,000 m. For undiscovered gas fields, dril ing depths ranged from $1,000 \mathrm{~m}$ at the minimum to a median of 2,500 m, and a maximum of $8,000 \mathrm{~m}$. Estimates of water depths for undiscovered oil and gas accumulations are a minimum of $0 \mathrm{~m}$, a median of $100 \mathrm{~m}$, and a maximum of $400 \mathrm{~m}$.

\section{Assessment Results}

The assessment results for undiscovered conventional oil and gas resources in the Northern West Siberian Mesozoic Composite TPS of the West Siberian Basin Province are summarized in table 1 and are included in the assessment summary 
of Gautier and others (2009). The results in the upper part of table 1 reflect the assessment of the entire AU areas; the lower part of table 1 reflects only those portions of each AU that are north of the Arctic Circle (fig. 8), as reported in the Circum Arctic assessment summary.

\section{Assessment Results-Entire AU areas}

For the Northern West Siberian Onshore Gas AU, the mean undiscovered resource estimates are 1,601 MMBO, 40,663 BCFG, and 1,181 MMBNGL (table 1). For the South Kara Sea Offshore AU the mean undiscovered resource estimates are 2,507 MMBO, 622,222 BCFG, and 19,479 MMBNGL. For the two AUs in the Northern West Siberian Basin Mesozoic Composite TPS, the total mean undiscovered resource estimates are 4,108 $\mathrm{MMBO}, 662,884 \mathrm{BCFG}$, and 20,659 MMBNGL.

\section{Assessment Results-AU Areas North of Arctic Circle}

For the area of the Northern West Siberian Onshore Gas AU north of the Arctic Circle, the mean undiscovered resource estimates are 1,152 $\mathrm{MMBO}, 27,377 \mathrm{BCFG}$, and 850 MMBNGL. For the South Kara Sea Offshore AU the mean undiscovered resource estimates are 2,507 MMBO, 622,222 BCFG, and 19,479 MMBNGL, as the AU is entirely north of the Arctic Circle.

For the total area of the Northern West Siberian Basin Mesozoic Composite TPS north of the Arctic Circle, the total mean undiscovered resource estimate are 3,659 MMBO, 651,499 BCFG, and 20,329 MMBNGL.

The ranges of estimates (F95, F5) reflect the geologic uncertainty at the time of the assessment, and the ranges of resource estimates particularly illustrated this uncertainty for the South Kara Sea Offshore AU. Detailed assessment results for the Northern West Siberian Onshore Gas AU and the South Kara Sea Offshore AU are in Appendix 3 and Appendix 4, respectively.

The assessment results presented here reflect the state of geologic knowledge of the northern part of the West Siberian Basin Province at the time of the assessment (2008). Future drilling and evaluation of the petroleum systems within the province will greatly add to the geologic knowledge base, and will lead to a refinement of these assessment results, partic larly for the South Kara Sea Offshore AU. 


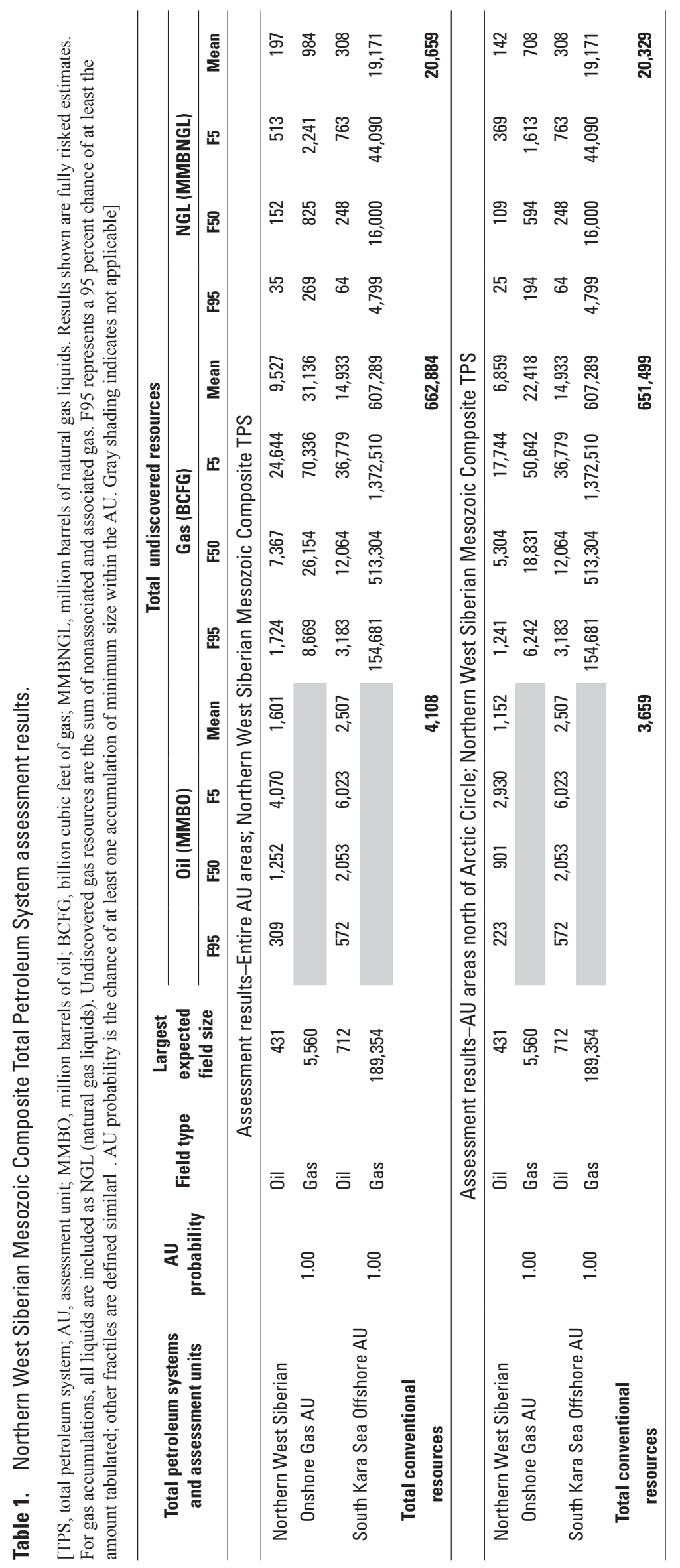




\section{References Cited}

Allen, M.B., Anderson, Lester, Searle, R.C., and Buslov, Misha, 2006, Oblique rift geometry of the West Siberian Basin-Tectonic setting for the Siberian flood basalts: Jou nal of the Geological Society, v. 163, no. 6, p. 901-904.

Aplonov, S.V., 1995, The tectonic evolution of West SiberiaAn attempt at a geophysical analysis: Tectonophysics, v. 245, no. 1-2, p. 61-84.

Ayarza, P., Brown, D., Alvarez-Marron, J., and Juhlin, C., 2000, Contrasting tectonic history of the arc-continent suture in the southern and middle Urals-Implications for the evolution of the orogen: Journal of the Geological Society, v. 157, no. 5, p. 1065-1076.

Barboza, S.A., Burshtein, L., Fjellanger, Erik, Kontorovich, A.E., and Livshits, V.R., 2007, 3D basin simulation and hydrocarbon systems analysis of the West Siberia Basin [abs.]: American Association of Petroleum Geologists, Search and Discovery Article \#90072, European Region Conference 2007, Athens, Greece.

Brown, D., 2009, The growth and destruction of continental crust during arc-continent collision in the southern Urals: Tectonophysics, v. 479, no. 1-2, p. 185-196.

Brown, D., Alvarez-Marrón, J., Pérez-Estaún, A., Gorozhanina, Y., Baryshev, V., and Puchkov, V., 1997, Geometric and kinematic evolution of the foreland thrust and fold belt in the southern Urals: Tectonics, v. 16, no. 3, p. 551-562.

Charpentier, R.R., Klett, T.R., and Attanasi, E.D., 2008, Database for assessment unit-scale analogs (exclusive of the United States): U.S. Geological Survey Open-File Report 2007-1404, 61 p. [Also available at https://pubs.usgs.gov/ of/2007/1404/.]

Cherepanova, Yulia, Artemieva, I.M., Thybo, Hans, and Chemia, Zurab, 2013, Crustal structure of the Siberian craton and the West Siberia Basin-An appraisal of existing seismic data: Tectonophysics, v. 609, p. 154-183.

Cramer, B., Poelchau, H.S., Gerling, P., Lopatin, N.V., and Littke, R., 1999, Methane released from groundwaterThe source of natural gas accumulations in northern West Siberia: Marine and Petroleum Geology, v. 16, no. 3, p. 225-244.

Davies, Clare, Allen, Mark, Buslov, Mikhail, Safonova, Inna, and Soloboeva, Elena, 2005, Insights into the formation and sedimentary fill of the West Siberian Basin-Structural, sedimentological, and provenance analysis [abs.]: American Association of Petroleum Geologists Search and Discovery Article \#90039, Annual Meeting 2005, Calgary, Alberta, Canada.
Fomin, A.N., Kontorovich, A.E., Krasavchikov, V.O., and Istomin, A.V., 2007, Organic matter catagenesis and petroleum potential of Mesozoic deposits of West Siberia [abs.]: European Association of Organic Geochemists, 23rd International Meeting on Organic Geochemistry, p. 75.

Friberg, M., Juhlin, C., Beckholmen, M., Petrov, G.A., and Green, A.G., 2002, Paleozoic tectonic evolution of the Middle Urals in the light of ESRU seismic experiments: Journal of the Geological Society, v. 159, no. 3, p. 295-306.

Galushkin, Yuri, Simonenkova, Olga, and Lopatin, N.V., 1999, Thermal and maturation modeling of the Urengoy Field, West Siberian Basin-Some special considerations in basin modeling: American Association of Petroleum Geologists Bulletin, v. 83, no. 12, p. 1965-1979.

Gautier, D.L., Bird, K.J., Charpentier, R.R., Grantz, Arthur, Houseknecht, D.W., Klett, T.R., Moore, T.E., Pitman, J.K., Schenk, C.J., Schuenemeyer, J.H., Sorensen, Kai, Tennyson, M.E., Valin, Z.C., and Wandrey, C.J., 2009, Assessment of undiscovered oil and gas in the Arctic: Science, v. 324, no. 5931, p. 1175-1179.

Gavura, V.E., and Rovenskaya, A.S., 2002, Largest West Siberia oil and gas bearing basin - Giant and unique petroleum systems [abs.]: American Association of Petroleum Geologists Search and Discovery Article \#90007, Annual Meeting 2002, Houston, Texas.

Gogonenkov, G.N., 2009, Strike-slip dislocations in the north of West Siberian Basin [abs.]: American Association of Petroleum Geologists Search and Discovery Article \#90096, 3P Arctic_-Polar Petroleum Potential Conference and Exhibition 2009, Moscow, Russia.

Görz, Ines, and Hielscher, Peggy, 2010, An explicit plate kinematic model for the orogeny in the southern Uralides: Tectonophysics, v. 493, no. 1-2, p. 1-26.

Hamilton, Warren, 1970, The Uralides and the motion of the Russian and Siberian platforms: Geological Society of America Bulletin, v. 81, no. 9, p. 2553-2576.

Hegre, J.A., Pittion, J.L., Herbin, J.P., and Lopatin, N.V., 1998, Geochemical modeling in an organic-rich source rock-The Bazhenov Formation: Geological Society of London, Special Publication 141, p. 157-167.

Holt, P.J., van Hunen, Jeroen, and Allen, M.B., 2012, Subsidence of the West Siberian Basin-Effects of a mantle plume impact: Geology, v. 40, no. 8, p. 703-706.

Igoshkin, Vladimir, Dolson, John, Siderov, Dimitry, Bakuev, Oleg, and Herbert, Richard, 2008, New interpretations of the evolution of the West Siberian Basin, Russia-Implications for exploration: American Association of Petroleum Geologists Search and Discovery Article \#10161, 35 p. 
IHS Energy, 2007, International Oil and Gas Field Database-2006 update: Englewood, Colo., IHS Energy Corporation.

Ivanov, A.V., He, Huayiu, Yan, Liekun, Ryabov, V.V., Shevko, A.Y., Palesskii, S.V., and Nikolaeva, I.V., 2013, Siberian traps large igneous province-Evidence for two flood basal pulses around the Permo-Triassic boundary and in the Middle Triassic, and contemporaneous granitic magmatism: Earth-Science Reviews, v. 122, p. 58-76.

James, R.A., 1995, Post-Jurassic tectonism in the West Siberian Basin, Russia: Journal of Petroleum Geology, v. 18, no. 2, p. 125-148.

Juhlin, C., Friberg, M., Echtler, H.P., Hismatulin, T., Rybalka, A., Green, A.G., and Ansorge, J., 1998, Crustal structure of the Middle Urals - Results from the (ESRU) Europrobe seismic reflection profiling in the Urals experiments Tectonics, v. 17, no. 5, p. 710-725.

Katz, B.J., Robison, C.R., and Chakhmakhchev, A., 2002, Aspects of hydrocarbon charge of the petroleum system of the Yamal Peninsula, West Siberia basin [abs.]: The Society of Organic Petrology, $18^{\text {th }}$ Annual Meeting Program and Abstracts, Houston, Texas, Poster Presentation, p. 58.

Kontorovich, V.A., 2009, The Meso-Cenozoic tectonics and petroleum potential of West Siberia: Russian Geology and Geophysics, v. 50, no. 4, p. 346-357.

Kontorovich, V.A., Moskvin, V.I., Bostrikov, O.I., Danilova, V.P., Fomin, A.N., Fomichev, A.S., Kostyreva, E.A., and Melenevsky, V.N., 1997, Main oil source formations of the West Siberian Basin: Petroleum Geoscience, v. 3, no. 4, p. 343-358.

Leonard, C., Leonard, J., Nemchenko, N., Nemchenko, T., Rovenskaya, A., and Girshgorn, S., 2001, Petroleum systems in deep formations of the northern part of West Siberia on the basin-modeling basis [abs.]: American Association of Petroleum Geologists Search and Discovery Article \#90906; Annual Convention 2001, Denver, Colo.

Littke, R., Cramer, B., Gerling, P., Lopatin, N.V., Poelchau, H.S., Schaefer, R.G., and Welte, D.H., 1999, Gas generation and accumulation in the West Siberian Basin: American Association of Petroleum Geologists Bulletin, v. 83, no. 10, p. 1642-1665.

Lopatin, N.V., 2013, The petroleum systems and effective source rocks on the South Kara Sea and North West Siberian Basin [abs.]: American Association of Petroleum Geologists Search and Discovery Article \#90177, 3P Arctic-Polar Petroleum Potential Conference and Exhibition 2013, Stavanger, Norway.
Malyshev, Nikolay, Nikishin, Valeriy, Nikishin, Anatoly, Obmetko, Victor, Reydik, Juriy, and Ikhsanov, Bulat, 2011, Geological settings and evolution of the South and North Kara Basins [abs.]: American Association of Petroleum Geologists Search and Discovery Article \#90130, 3P Arctic-Polar Petroleum Potential Conference and Exhibition 2011, Halifax, Nova Scotia, Canada.

Matusevich, V.M., Myasnikova, G.P., Maximov, E.M., Volkov, A.M., Chistiakova, N.F., Kanalin, V.G., and Pupilli, M., 1997, Abnormal formation pressures in the West Siberian Mega-basin, Russia: Petroleum Geoscience, v. 3, no. 3, p. 269-283.

Milkov, A.V., 2010, Methanogenic biodegradation of petroleum in the West Siberian Basin (Russia) — Significance for formation of giant Cenomanian gas pools: American Association of Petroleum Geologists Bulletin, v. 94, no. 10, p. 1485-1541.

Murris, R.J., 2001, Gas generation and accumulation in the West Siberian Basin-Discussion: American Association of Petroleum Geologists Bulletin, v. 85, no. 10, p. 1891-1892.

Nesterov, I.I., Salvamanov, F.K., Kontorovich, A.E., Kulakhmetov, N.K., Surkov, V.S., Trofimuk, A.A., and Shpilman, V.I., 1990, West Siberian oil and gas superprovince: Geological Society of London, Special Publication 50, p. 491-502.

Otto, S.C., and Bailey, R.J., 1995, Tectonic evolution of the northern Ural orogen: Journal of the Geological Society, v. 152, no. 6, p. 903-906.

Peters, K.E., Kontorovich, A.E., Huizinga, B.J., Moldowan, J.W., and Lee, C.Y., 1994, Multiple oil families in the West Siberian Basin: American Association of Petroleum Geologists Bulletin, v. 78, no. 6, p. 893-909.

Peters, K.E., Kontorovich, A.E., Moldowan, J.M., Andrusevich, V.E., Huizinga, B.J., Demaison, G.J., and Stasova, O.F., 1993, Geochemistry of selected oils and source rocks from the central portion of the West Siberian Basin, Russia: American Association of Petroleum Geologists Bulletin, v. 77 , no. 5 , p. 863-887.

Petersen, J.A., and Clarke, J.W., 1989, West Siberian oilgas province: U.S. Geological Survey Open-File Report 89-192, 142 p.

Pinous, O.V., Sahagian, D.L., Shurygin, B.N., and Nikitenko, B.L., 1999, High-resolution sequence stratigraphic analysis and sea-level interpretation of the middle and upper Jurassic strata of the Nyurolskaya depression and vicinity (southeastern West Siberia, Russia): Marine and Petroleum Geology, v. 16, no. 3, p. 245-257. 
Pinous, O.V., Levchuk, M.A., and Sahagian, D.L., 2001, Regional synthesis of the productive Neocomian complex of West Siberia-sequence stratigraphic framework: American Association of Petroleum Geologists Bulletin, v. 85, no. 10, p. 1713-1730.

Puchkov, V.N., 2009, The evolution of the Uralian orogen: Geological Society of London, Special Publication 327, p. 161-195.

Reichow, M.K., Saunders, A.D., White, R.V., Al-Mukhamedov, A.I., and Medvedev, A.Y., 2005, Geochemistry and petrogenesis of basalts from the West Siberian Basin-An extension of the Permo-Triassic Siberian traps, Russia: Lithos, v. 79, no. 3-4, p. 425-452.

Rigassi, D.A., 1986, Wrench faults as a factor controlling petroleum occurrences in West Siberia, in Halbouty, M.T., ed., Future petroleum provinces of the world: American Association of Petroleum Geologists Memoir 40, p. 529-544.

Saunders, A.D., England, R.W., Reichow, M.K., and White, R.V., 2005, A mantle plume origin for the Siberian trapsUplift and extension in the West Siberian Basin, Russia: Lithos, v. 79, no. 3-4, p. 407-424.

Savchenko, V.I., Henriksen, Erik, Kirjukhina, T.A., Ogarkova, Maria, Panarin, Ivan, and Kurasov, Ivan, 2009, Extensional basins in the northern West Siberia and Kara Sea [abs.]: American Association of Petroleum Geologists Search and Discovery Article \#90096, 3P Arctic_-Polar Petroleum Potential Conference and Exhibition 2009, Moscow, Russia.

Savelieva, G.N., and Nesbitt, R.W., 1996, A synthesis of the stratigraphic and tectonic setting of the Uralian ophiolites: Journal of the Geological Society, v. 153, no. 4, p. 525-537.

Scarrow, J.H., Ayala, Conxi, and Kimbell, G.S., 2002, Insights into orogenesis - Getting to the root of a continent-oceancontinent collision, southern Urals, Russia: Journal of the Geological Society, v. 159, no. 6, p. 659-671.
Schaefer, R.G., Galushkin, Y.I., Kolloff, Antje, and Littke, Ralf, 1999, Reaction kinetics of gas generation in selected source rocks of the West Siberian Basin-Implications for the mass balance of early-thermogenic methane: Chemical Geology, v. 156, no. 3-4, p. 41-65.

Scott, Robert, Bogolepova, O.K., Pease, V.L., Gubanov, A.P., Howard, J.P., Carter, Andy, Soloviev, Alexei, and Reichow, Marc, 2010, The Uralian orogen in Arctic Russia and its significance for adjacent hydrocarbon basins [abs.]: American Association of Petroleum Geologists Search and Discovery Article \#90108, International Convention and Exhibition 2010, Calgary, Alberta, Canada.

Surkov, V.S., Smirnov, L.V., Gurari, F.G., Devyatov, V.P., and Ekhanin, A.E., 2004, Lower-Middle Jurassic complex of the West Siberian plate-Structure and petroleum potential: Russian Geology and Geophysics, v. 45 no. 1, p. 55-58.

Ulmishek, G.F., 2000, West Siberian Basin-Geologic Province 1174, in U.S. Geological Survey World Energy Assessment Team, U.S. Geological Survey World Petroleum Assessment 2000 - description and results: U.S. Geological Survey Digital Data Series DDS-60, four CD-ROM set, Disk 2.

Ulmishek, G.F, 2003, Petroleum geology and resources of the West Siberian Basin, Russia: U.S. Geological Survey Bulletin 2201-G, 49 p.

Vyssotski, A.V., Vyssotski, V.N., and Nezhdanov, A.A., 2006, Evolution of the West Siberian Basin: Marine and Petroleum Geology, v. 23, no. 1, p. 93-126.

Yuri, Z.N., Eder, V.G., and Zamirailova, A.G., 2008, Composition and formation environments of Upper Jurassic-Lower Cretaceous black shale Bazhenov Formation (the central part of the West Siberian Basin): Marine and Petroleum Geology, v. 25, no. 3, p. 289-306. 


\section{Appendixes}

Appendixes are available online only, and may be accessed at https://doi.org/10.3133/pp1824Q.

Appendix 1. Input Data for the Northern West Siberian Onshore Gas Assessment Unit.

Appendix 2. Input Data for the South Kara Sea Offshore Assessment Unit.

Appendix 3. Detailed assessment results for the Northern West Siberian Onshore Gas Assessment Unit.

Appendix 4. Detailed assessment results for the South Kara Sea Offshore Assessment Unit. 


\section{兽}

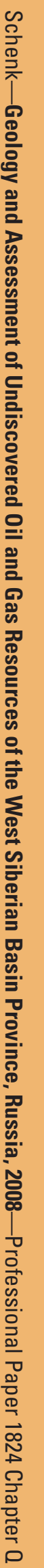

